OPEN ACCESS

Edited by:

Tullio Genova,

University of Turin, Italy

Reviewed by:

Alla B. Salmina,

Krasnoyarsk State Medical University,

Russia

Bingmei M. Fu,

City College of New York (CUNY),

United States

*Correspondence:

David Redmond

dar2042@med.cornell.edu

Raphaël Lis

ral2020@med.cornell.edu

Specialty section:

This article was submitted to

Vascular Physiology,

a section of the journal

Frontiers in Physiology

Received: 16 December 2020 Accepted: 08 March 2021

Published: 31 March 2021

Citation:

Lu TM, Barcia Durán JG,

Houghton S, Rafii S, Redmond D and

Lis $R$ (2021) Human Induced

Pluripotent Stem Cell-Derived Brain

Endothelial Cells: Current

Controversies.

Front. Physiol. 12:642812.

doi: 10.3389/fphys.2021.642812

\section{Human Induced Pluripotent Stem Cell-Derived Brain Endothelial Cells: Current Controversies}

\author{
Tyler M. Lu',2, José Gabriel Barcia Durán', Sean Houghton', Shahin Rafii', \\ David Redmond ${ }^{1 *}$ and Raphaël Lis ${ }^{1,2 *}$
}

1 Division of Regenerative Medicine, Department of Medicine, Ansary Stem Cell Institute, Weill Cornell Medicine, New York, NY, United States, ${ }^{2}$ Ronald O. Perelman and Claudia Cohen Center for Reproductive Medicine, Weill Cornell Medicine, New York, NY, United States

Brain microvascular endothelial cells (BMECs) possess unique properties that are crucial for many functions of the blood-brain-barrier (BBB) including maintenance of brain homeostasis and regulation of interactions between the brain and immune system. The generation of a pure population of putative brain microvascular endothelial cells from human pluripotent stem cell sources (iBMECs) has been described to meet the need for reliable and reproducible brain endothelial cells in vitro. Human pluripotent stem cells (hPSCs), embryonic or induced, can be differentiated into large quantities of specialized cells in order to study development and model disease. These hPSC-derived iBMECs display endothelial-like properties, such as tube formation and low-density lipoprotein uptake, high transendothelial electrical resistance (TEER), and barrier-like efflux transporter activities. Over time, the de novo generation of an organotypic endothelial cell from hPSCs has aroused controversies. This perspective article highlights the developments made in the field of hPSC derived brain endothelial cells as well as where experimental data are lacking, and what concerns have emerged since their initial description.

Keywords: induced pluripotent stem cells, endothelial cell, epithelial cell, cell fate and differentiation, misclassification, brain-blood barrier (BBB), disease modeling

\section{INTRODUCTION}

The latest efforts to develop drugs targeting neurodegeneration and neurological disorders have been met with disappointment in recent clinical trials. The relative ineffectiveness of those drugs has incited the scientific community to develop better pre-clinical models by improving human cell-based models to capture the complexity of the brain. While the discovery of induced pluripotent stem cells and subsequent generation of brain organoids has advanced innovative avenues, these brain organoids are still rudimentary, lacking primordial non-neuronal cell types of the central nervous system (CNS) like microglia and most importantly functional blood vessels. During embryonic development, endothelial cells (ECs) acquire unique organ-specific molecular and cellular specializations that are crucial for the formation of the blood-brain-barrier (BBB) and therefore the maintenance of brain homeostasis. Human pluripotent stem cells (hPSCs), embryonic or induced, have been used in an effort to generate large quantities of specialized cells for development studies and disease modeling. The use of hPSCs to generate a pure population of 
these specialized brain microvascular ECs (iBMECs) has been described to meet the need for a reliable and reproducible in vitro BBB model. Specifically, it has been reported that hPSC-derived iBMECs display EC-like properties including tube formation, low density lipoprotein uptake, high transendothelial electrical resistance (TEER), and select barrier-like transporter activity. Over time, this de novo generation of an organotypic endothelial cell from hPSCs has aroused controversies. This perspective article highlights the developments made in the field of hPSC derived brain endothelial cells as well as where experimental data are lacking, and what concerns have emerged since their initial description.

\section{FROM GENERIC TO CNS SPECIFIC ENDOTHELIAL CELLS}

Brain endothelial cells plays an essential role in the development of a multicellular vascular structure separating the central nervous system (CNS) from the peripheral blood circulation (Bär, 1980; Risau and Wolburg, 1990; Engelhardt, 2003). In mammals, this process begins when cells originating from the mesoderm, known as angioblasts, enter the head region and form the perineural vascular plexus (PNVP) which will go on to encompass the neural tube by mid-gestation. None of the microvasculature in the CNS is derived from the neuroectoderm but instead, new vessels sprout from the existing PNVP into the developing neuroectoderm (Risau and Wolburg, 1990; Engelhardt, 2003). This process is highly regulated, occurring at precise stages of embryonic development, thus leading to the formation of a reproducible pattern of neuro-vasculature in all mammals (Aird, 2007a,b).

Initial signs for CNS angiogenesis and induction of BBB traits are given by the neural microenvironment on embryonic day E10 in mice (Obermeier et al., 2013). Endothelial cell progenitors from the PNVP infiltrate the neuroectoderm following a gradient of vascular endothelial growth factor (VEGF), resulting in the development of nascent "leaky" or "immature" blood vessels (Potente et al., 2011). Activation of the Wnt/ $\beta$-catenin pathway in these nascent blood vessels triggers the expression of genes critical for the formation of the BBB. Wnt ligands secreted by the neural microenvironment bind to a set of receptors expressed by the endothelial cells (Frizzled, LRP5, LRP6) to elicit the expression of GLUT1, DR6, and TROY (Stenman et al., 2008; Tam et al., 2012). Furthermore, G-protein coupled receptor 124 (GPR124) seems to be essential for barrier genesis in the brain as it acts as an endothelial specific co-activator of $\mathrm{Wnt} / \beta$-catenin signaling in the $\mathrm{BBB}$ (Kuhnert et al., 2010; Anderson et al., 2011; Cullen et al., 2011). By day E15 an embryonic BBB is formed in mice (Daneman et al., 2010; Ben-Zvi et al., 2014); however, the exact timing of BBB formation in human development and whether humans are born with a fully mature BBB remains unclear (Saunders et al., 2013).

This primitive $\mathrm{BBB}$ further mature by recruiting pericytes to the developing blood vessels. This step is critical to ensure proper BBB formation and function (Armulik et al., 2010;
Bell et al., 2010; Daneman et al., 2010; Vanlandewijck et al., 2018). A recent study deconvoluted the complexity of the endothelial responses to pericytes at the single cell level (Andaloussi Mae et al., 2020). Activation of endothelial TIE2 signaling by ANGPT2 secreted by pericytes reinforce endothelial arteriovenous zonation, angiogenic quiescence and a limited set of BBB functions. It was also shown that the last component of the $\mathrm{BBB}$, astrocytes, support the endothelial cells in acquiring BBB attributes and barrier properties (Alvarez et al., 2011).

\section{ORGANOTYPIC PROPERTIES OF BRAIN MICROVASCULAR ENDOTHELIAL CELLS}

The major endothelial transport systems, ions channels and GPCRs are described in detail elsewhere (Daneman and Prat, 2015; Vanlandewijck et al., 2018; Hariharan et al., 2020). The unique cellular junction molecules expressed by brain endothelial cells are briefly discussed below.

The $\mathrm{BBB}$ is lined with specialized endothelial cells (EC) known as brain microvascular endothelial cells (BMEC) that possess intercellular tight junctions (TJs), lack fenestrations, and greatly limit transcytosis. BMECs, acting in conjunction with various neural cell types and non-cellular elements, form the $\mathrm{BBB}$ which regulates the dynamic transfer of select molecules into and out of the CNS (Zlokovic, 2008; Daneman et al., 2009; Daneman, 2012). These properties are achieved through the presence of distinctive TJs exhibiting a high trans-endothelial electrical resistance (TEER) in vivo and reduced caveolar-mediated transport, along with the presence of selective transporters. Due to their significant structural and functional overlap, most of the current understanding of endothelial cell TJs has been derived from examination of their epithelial counterparts (MDCK, CACO2, and ECV304) (Garberg et al., 2005). However, BBB-endothelial TJs hold many unique attributes which may be more akin to ECs of other organs when paracellular permeability and dynamic regulation are evaluated under pathophysiological conditions.

The establishment and maintenance of BBB TJs are governed by mainly three transmembrane proteins: Claudins, Occludin, and Junction Adhesion Proteins (JAM). The Claudin family is comprised of at least 24 member proteins which contain two extracellular loops responsible for homophilic interaction as well as establishing a link with claudins of contiguous endothelial cells. This homophilic interaction forms the primary seal of the TJ in vivo (Piontek et al., 2008) with Claudin $1,-3,-5$, and -12 initially thought to be expressed by BBBforming ECs. While some studies showed immunostaining against Claudin-1 at the BBB in rodent models (Liebner et al., 2000), it has since been shown that it is not expressed by BBB-forming ECs (Pfeiffer et al., 2011). Likewise, while some research groups have reported that brain microvasculature expresses Claudin-3 (Wolburg et al., 2003), others could not reproduce or confirm this observation (Kominsky et al., 2007; Steinemann et al., 2016). The generation of a Claudin$3^{-/-}$mice demonstrated that the junctional immunostaining 
produced by anti-Claudin-3 antibodies in mouse brain ECs in situ and in vitro is not due to the presence of Claudin3 but rather to an endothelial junctional antigen that is still present in brain ECs of Claudin $-3^{-/}$mice (Castro Dias et al., 2019). Of note, it is now known that Claudin-1 and 3 are selectively expressed by the epithelium of the choroid plexus (Steinemann et al., 2016). Thus, these contradictory observations emphasize the contentious reliability of assessing Claudin protein expression in BBB TJs though their transcript expression still remain an important measure of cell specific tight junctions.

Another barrier property of the BBB lies in their ability to restrict immune cell infiltration to the CNS as BMECs generally has a low expression of leucocyte adhesion molecules during homeostatic conditions (Reese and Karnovsky, 1967; Brightman and Reese, 1969; Westergaard and Brightman, 1973). Immune cell trafficking across the BBB during pathophysiological conditions have been extensively studied in animal models of neuroinflammatory disease. These studies highlight the unique interaction of immune cells with BMECs which is regulated by a sequential cascade of different signaling pathways involving various adhesion molecules. BMECs harbor unique intrinsic properties which allow them to adapt and respond to inflammatory cues and thereby regulate immune cell trafficking through the BBB. BMECs exposed to $\mathrm{TNF} \alpha$, IL- $1 \beta$, and IL- 6 have shown increased paracellular permeability as well as acquiring an activated phenotype (de Vries et al., 1996).

These phenotypical modifications, unique to the vascular cells, are mainly characterized by an induced expression of endothelial cellular adhesion molecules that are critical for the recruitment of circulating leukocytes to sites of inflammation. The importance of ICAM-1 in regulating leukocyte recruitment during neuroinflammation has been highlighted in different animal models using both ICAM-1-null mice and ICAM-1blocking antibodies (Zhang Rui et al., 1995; Kitagawa et al., 1998). An in vivo study in mice showed that E-selectin deficiency exert a neuroprotective effect characterized by reduced inflammation and neuronal apoptosis (Ma et al., 2012). Additionally, genetic P-selectin knock-in mice show increased BBB permeability and stroke injury (Kisucka et al., 2009). Hence, any BMEC cultured in vitro must be able to phenocopy this response to inflammatory stimuli in order to be considered physiologically relevant $\mathrm{BBB}$ model.

\section{A BRIEF OVERVIEW OF IN VITRO BLOOD BRAIN BARRIER MODELS}

The development of in vitro models has accelerated mechanical studies on the $\mathrm{BBB}$ as well as large scale screening of drugs with potential to penetrate the brain, with some limitations. Many studies have been conducted using primary BMEC isolated from various animal tissues, most commonly bovine, porcine, and rodent (Dehouck et al., 1990; Gaillard et al., 2001; Deli et al., 2005; Roux and Couraud, 2005; Zhang et al., 2006; Burek et al., 2012; Yusof et al., 2014; Helms et al., 2016;
Veszelka et al., 2018). BMECs isolated from larger animal models generally possess higher TEER, at around $800 \Omega . \mathrm{cm}^{2}$ (Rubin et al., 1991), and low permeability due to high expression of junctional markers such as claudin-5, ZO-1, and occludin (Rubin et al., 1991; Cecchelli et al., 2007; Cohen-Kashi Malina et al., 2009; Patabendige et al., 2013). In particular, bovine and porcine brain ECs can be isolated in large quantities with ease; as a result, they have become the preferred choice for many permeability and transcytosis studies. Rodent brain ECs, specifically mouse or rat, have also been widely used as an in vitro model of the BBB with some groups developing immortalized cell lines (Roux et al., 1994; Wagner and Risau, 1994; Burek et al., 2012) and others discovering the use of Puromycin to increase the purity of primary isolations (Perrière et al., 2005; Calabria et al., 2006). Brain ECs these models generally possess lower TEER (under $300 \Omega . \mathrm{cm}^{2}$ ) (Daneman et al., 2010) but offer an avenue for $\mathrm{BBB}$ studies in transgenic models. Models using rodent brain ECs also provide the opportunity for large cohort studies and cells which can be targeted by many established antibodies.

These animal BMECs have also been studied in many coculture conditions allowing for the discovery of many important cellular interactions between BMECs, astrocytes, and pericytes in the neurovascular microenvironment (Gaillard et al., 2001; Coisne et al., 2005; Garberg et al., 2005; Nakagawa et al., 2007; Helms et al., 2010, 2012; Liu et al., 2014). These coculture models also possess higher TEER with the larger animal models exceeding 2,500 $\Omega . \mathrm{cm}^{2}$ in some studies (Helms et al., 2014). Over time, BBB models developed using these various animal cell lines have demonstrated well-characterized permeability phenotypes and physiological similarities to human BMECs (Warren et al., 2009; Shawahna et al., 2011; Uchida et al., 2011; Hoshi et al., 2013). For instance, bovine co-culture models possess highly differentiated junctions which allow for various permeability and junction modulation assays using drug compounds (Wolburg et al., 1994; Gaillard and de Boer, 2000; Schaddelee et al., 2003; Boveri et al., 2006; Bohara et al., 2014). Rodent co-culture conditions utilizing single or multiple neural cell types have been shown to successfully mimic the neurovascular unit and even induce certain BBB phenotypes such as elevated TEER in vitro which has been validated by small molecule permeability screening (Coisne et al., 2005; Nakagawa et al., 2007, 2009; Abbott et al., 2012; Watson et al., 2013). Animal BBB models have provided a wealth of insight into various aspects of $\mathrm{BBB}$ physiology and pathology with a large amount of cross-validation between models. However, recent advances in the field have illuminated aspects in which animal models are lacking such as precise reproducibility with certain models showing a wide range of varied TEER and junctional phenotypes between laboratories (Schaddelee et al., 2003; Helms et al., 2014).

In an effort to generate a completely homologous model for clinical research and drug development, human primary BMECs have also been used in in vitro BBB models but are difficult to procure in sufficient numbers for experimental purposes (Bernas et al., 2010). Though human BMECs have provided a useful model for the study of many developmental and 
regulatory neurovascular pathways, the ethical questions and general restrictions placed on obtaining healthy human brain tissue along with low BMEC yields during isolation places a substantial limitation on their use in in vitro studies (Bernas et al., 2010). In addition, often times human BMECs offered by commercial vendors lack detailed documentation as to the isolation and sourcing of the cells, creating concerns over their use in many physiological models (Helms et al., 2016). The barrier properties and endothelial identity of primary BMECs are also not well maintained in vitro for extended periods of time, rendering them suboptimal for a number of potential BBB assays (Helms et al., 2016).

In order to overcome these limitations, immortalized human BMEC lines were established (Stins et al., 2001; Weksler et al., 2005; Rahman et al., 2016). These cells provided researchers with a model of human BMECs which was easy to use and had less batch variation availability issues. However, immortalized human BMECs also lose many of their brain specific EC attributes and produce a sub-physiologic TEER in vitro making them ineffective for functional studies (Urich et al., 2012; Weksler et al., 2013; Helms et al., 2016). It has also been reported that expression of endothelial tight junction specific CLDN5 is significantly lower in immortalized human BMECS than in vivo. Taken together, BMECs originating from either animal or human tissue origins lose some of their organotypic phenotypes when cultured in vitro (Urich et al., 2012; Weksler et al., 2013). The use of all the previously mentioned brain endothelial cells in various monoand co-culture conditions has highlighted the need for a stable in vitro $\mathrm{BBB}$ model possessing both vascular endothelial and barrier phenotypes (Helms et al., 2016).

\section{HUMAN PLURIPOTENT STEM CELL DIFFERENTIATION AS A POSSIBLE ALTERNATIVE}

Recently, Lippmann et al. (2012) have reported the generation of a pure population of putative BMECs from pluripotent stem cell sources (iBMECs) has been described to meet the need for a reliable and reproducible in vitro human $\mathrm{BBB}$ model. Human pluripotent stem cells, embryonic or induced, can differentiate into large quantities of specialized cells in order to study development and model disease. iBMECs are generated primarily through directed differentiation of pluripotent stem cells into both neural and endothelial progenitors followed by selective purification. Under these differentiation culture conditions, it is proposed that the neural cell types provide a microenvironmental cues that coax the emerging endothelial progenitors toward a BBB-specific phenotype as they further differentiate into ECs (Lippmann et al., 2012). Later iterations of this protocol reported that adding retinoic acid or inhibiting GSK3 during this neuro-endothelial differentiation process would enhance the yield and fidelity of these putative iBMECs (Lippmann et al., 2014; Qian et al., 2017; Faley et al., 2019). Additionally, others have developed a more defined serumfree method which aimed to improve the consistency of differentiated iBMECs while decreasing the overall length of the differentiation process (Hollmann et al., 2017; Neal et al., 2019) (Table 1). Regardless of the method used, these iBMECs display endothelial-like properties, such as tube formation and low-density lipoprotein uptake, high TEER $\left(\geq 800 \Omega . \mathrm{cm}^{2}\right)$, and barrier-like efflux transporter activities (Stebbins et al., 2016; Appelt-Menzel et al., 2017; Canfield et al., 2017; Hollmann et al., 2017; Lim et al., 2017; Stebbins Matthew et al., 2017; Vatine et al., 2017; Delsing et al., 2018; Sances et al., 2018). They have also been reported to express select BMEC marker transcripts such as PECAM1, CDH5, and CLDN5, among other BBB-specific markers (Qian et al., 2017; Vatine et al., 2017, 2019; Lee et al., 2018; Faley et al., 2019; Martins Gomes et al., 2019; Linville et al., 2020).

iBMECs generated using the original neuro-endothelial differentiation and subsequent protocols have quickly been adopted as a robust and viable source of human BMECs in many different in vitro studies of the BBB. At their inception, iBMECs were primarily used as a monoculture system to recapitulate the $\mathrm{BBB}$ in two-dimensional cell culture conditions. The cells were described to replicate barrier and transporter phenotypes present in the $\mathrm{BBB}$ in vivo in a cell-autonomous manner as well as respond to signaling from other neural cell types and microenvironmental changes. iBMECs cocultured with astrocytes and/or pericytes have been reported to have increased TEER to above $1,500 \Omega . \mathrm{cm}^{2}$ as well as expression of certain transporters and receptors present in the BBB such as SLC2A1, BCRP, MRP1, and LRP1 (Lippmann et al., 2012, 2014; Canfield et al., 2017; Qian et al., 2017; Vatine et al., 2017, 2019). Some groups have concluded that not only does the vascular endothelial identity of iBMECs remain stable in co-culture but that these conditions aid in the maturation of iBMECs into a more functional BBB model defined in large part by a decrease in dextran permeability through the barrier model.

Unsurprisingly, culturing these cells on a 2-D surface, regardless of the extra cellular matrix used, places observable limitations on cell-cell interactions including movement of secreted factors in the dish. These limitations would eventually lead to iBMECs being adapted to three-dimensional BBB models including various brain "organ-on-chip" models designed to have iBMECs interacting with various other cell types in 3-D (Sances et al., 2018; Faley et al., 2019). Some of these models also allow for flow to be introduced to the cells, further mimicking in vivo conditions (DeStefano et al., 2017; Vatine et al., 2019). Many groups have used 3-D iBMEC based models to further study the $\mathrm{BBB}$ under more physiologically relevant conditions; reporting data on permeability, gene expression, and barrier properties of iBMECs (Vatine et al., 2019; Linville et al., 2020). Over time, the use of both 2-D and 3-D iBMEC-based BBB models has led to many conclusions regarding the properties and functions of brain specific ECs which has added a lot of data to the field of $\mathrm{BBB}$ research. As a result of these reports, iBMECs have been widely accepted for use as a brain specific EC in many in vitro systems to assess BBB properties and function in homeostatic and disease models (Lippmann et al., 2012, 2013, 2014; Wilson et al., 2015; Stebbins et al., 2016; Appelt-Menzel et al., 2017; Canfield et al., 2017; Hollmann et al., 2017; Lim et al., 2017; Qian et al., 2017; Stebbins Matthew et al., 2017; Vatine et al., 2017, 2019; 
TABLE 1 | Major iterations of hPSC-derived iBMEC protocols.

\begin{tabular}{|c|c|c|c|c|c|c|c|c|c|}
\hline Year & References & Protocol & $\begin{array}{l}\text { Changes } \\
\text { vs. } 2012\end{array}$ & $\begin{array}{l}\text { Cell } \\
\text { line/Maintenance }\end{array}$ & $\begin{array}{l}\text { Differentiation } \\
\text { media }\end{array}$ & QPCR & Antibodies & Barrier assays & $\begin{array}{l}\text { Transporters/ } \\
\text { transcytosis }\end{array}$ \\
\hline 2012 & $\begin{array}{l}\text { Lippmann et al. } \\
\text { (2012). Nature } \\
\text { biotechnology }\end{array}$ & $\begin{array}{l}\text { (1) Prior diff cells are } \\
\text { passaged on } \\
\text { Matrigel (mTESR1 for } \\
2-3 \text { days. } \\
\text { (2). Media is switched to } \\
\text { lack of FGF (UM) for } \\
5-7 \text { days. } \\
\text { (3). Switch to EC media } \\
\text { human Endothelial } \\
\text { Serum-Free Medium } \\
\text { (Invitrogen) supplemented } \\
\text { with } 20 \text { ng/mL bFGF and } \\
1 \% \text { platelet-poor plasma } \\
\text { derived bovine serum32 } \\
\text { (PDS; Biomedical } \\
\text { Technologies, Inc.). } \\
\text { (4) 1-2 days of EC medium } \\
\text { treatment, cells were } \\
\text { dissociated with dispase } \\
\text { (2 mg/mL; Invitrogen) and } \\
\text { plated onto } 12 \text {-well tissue } \\
\text { culture polystyrene plates } \\
\text { and maintained in EC } \\
\text { media. }\end{array}$ & NA & $\begin{array}{l}\text { ES line: H9, IPS: } \\
\text { IMR90-4, } \\
\text { iPS-DF19-9-11T33, } \\
\text { iPS-DF6-9-9T. } \\
\text { Irradiated MEFS, } \\
\text { DMEMF12 } \\
\text { 20\%KOSR, } \\
\text { 1xMEM, } \\
\text { 1mM-Iglutamine, } \\
\text { 4ng.ml bFGF }\end{array}$ & $\begin{array}{l}\text { UM = lack of FGF } \\
\text { and } \\
\text { EC = Endothelial } \\
\text { Serum-Free } \\
\text { Medium (Invitrogen) } \\
\text { supplemented with } \\
20 \mathrm{ng} / \mathrm{mL} \text { bFGF } \\
\text { and } 1 \% \\
\text { platelet-poor } \\
\text { plasma derived } \\
\text { bovine serum32 } \\
\text { (PDS; Biomedical } \\
\text { Technologies, Inc.) }\end{array}$ & $\begin{array}{l}\text { PECAM1, CDH5, } \\
\text { vWF, LDLR, LRP1, } \\
\text { INSR, LEPR, } \\
\text { BCAM, TFRC, } \\
\text { AGER, STRA6, } \\
\text { SLC7A5, SLC1A1, } \\
\text { SLC38A5, } \\
\text { SLC16A1, } \\
\text { SLC2A1, ABCB1, } \\
\text { ABCG2, ABCC1, } \\
\text { ABCC2, ABCC4, } \\
\text { and ABCC5. } \\
\text { PLVAP, SLC21A14, } \\
\text { FST, FZD7, FZD4, } \\
\text { FZD6, STRA6, } \\
\text { LEF1, APCDD1, } \\
\text { SLC2A1, ABCB1 } \\
\text { Control: GAPDH, } \\
\text { NO EC CONTROL }\end{array}$ & $\begin{array}{l}\text { PECAM-1 (Rabbit, } \\
\text { Thermo Fisher) } \\
\text { CLAUDIN-5 } \\
\text { (Mouse, Invitrogen) } \\
\text { Occludin (Mouse, } \\
\text { Invitrogen) } \\
\text { P-glycoprotein } \\
\text { (Mouse, Thermo } \\
\text { Fisher) } \\
\text { GLUT-1a (Rabbit } \\
\text { antiserum) } \\
\text { VE-Cadherin } \\
\text { (Mouse, SCBT) } \\
\text { Nestin (Rabbit, } \\
\text { Millipore) } \\
\text { BIII tubulin (Rabbit, } \\
\text { Sigma) } \\
\text { Bcatenin } \\
\text { (FITC-conjugated } \\
\text { Mouse, BD } \\
\text { Biosciences) } \\
\text { Wnt7a FISH } \\
\text { Wnt7b FISH } \\
\text { GFAP (Polyclonal } \\
\text { Rabbit, Dako) } \\
\text { aSMA (Mouse, } \\
\text { American Research } \\
\text { Products) }\end{array}$ & $\begin{array}{l}\text { TEER, coculture } \\
\text { with rat astrocytes }\end{array}$ & $\begin{array}{l}\text { Inulin, sucrose, } \\
\text { glucose, vincristine, } \\
\text { colchicine, } \\
\text { prazosin, } \\
\text { diazepam, } \\
\text { rodhamine } 123 \\
\text { ((cyclosporine). No } \\
\text { EC control }\end{array}$ \\
\hline
\end{tabular}


TABLE 1 | Continued

\begin{tabular}{|c|c|c|c|c|c|c|c|c|c|}
\hline Year & References & Protocol & Changes vs. 2012 & $\begin{array}{l}\text { Cell } \\
\text { line/Maintenance }\end{array}$ & $\begin{array}{l}\text { Differentiation } \\
\text { media }\end{array}$ & QPCR & Antibodies & Barrier assays & $\begin{array}{l}\text { Transporters/ } \\
\text { transcytosis }\end{array}$ \\
\hline 2014 & $\begin{array}{l}\text { Lippmann et al. } \\
(2014) \text { Lippmann } \\
\text { et al., . Scientific } \\
\text { reports }\end{array}$ & $\begin{array}{l}\text { (1) Prior diff cells } \\
\text { are passaged on } \\
\text { Matrigel (mTESR1 } \\
\text { for 2-3 days. (2). } \\
\text { Media is switched } \\
\text { to lack of FGF (UM) } \\
\text { for 5-7 days. } \\
\text { (3). Switch to EC } \\
\text { media human } \\
\text { Endothelial } \\
\text { Serum-Free } \\
\text { Medium (Invitrogen) } \\
\text { supplemented with } \\
20 \text { ng/mL bFGF } \\
\text { and 1\% } \\
\text { platelet-poor } \\
\text { plasma derived } \\
\text { bovine serum32 } \\
\text { (PDS; Biomedical } \\
\text { Technologies, Inc.). } \\
\text { (4). 1-2 days of EC } \\
\text { medium treatment, } \\
\text { cells were } \\
\text { dissociated with } \\
\text { dispase (2 mg/mL; } \\
\text { Invitrogen) and } \\
\text { plated onto 12-well } \\
\text { tissue culture } \\
\text { polystyrene plates } \\
\text { and maintained in } \\
\text { EC media (RA }\end{array}$ & $\begin{array}{l}\text { Addition of Retinoic } \\
\text { Acid on day } 6 \text { use } \\
\text { of versene to } \\
\text { dissociate the cells } \\
\text { instead of dispase, } \\
\text { results in less } \\
\text { debris }\end{array}$ & $\begin{array}{l}\text { IMR90-4 and } \\
\text { DF19-9-11T iPSCs } \\
\text { and H9 hESCs in } \\
\text { mTESR or } 2012\end{array}$ & $\begin{array}{l}\text { UM = lack of FGF } \\
\text { and } \\
\text { EC = Endothelial } \\
\text { Serum-Free } \\
\text { Medium (Invitrogen) } \\
\text { supplemented with } \\
20 \text { ng/mL bFGF } \\
\text { and } 1 \% \\
\text { platelet-poor } \\
\text { plasma derived } \\
\text { bovine serum32 } \\
\text { (PDS; Biomedical } \\
\text { Technologies, } \\
\text { Inc.) + RA }\end{array}$ & $\begin{array}{l}\text { ABCB1, ABCG2, } \\
\text { ABCC1, ABCC2, } \\
\text { ABCC5, and } \\
\text { STRA6 }\end{array}$ & $\begin{array}{l}\text { PECAM-1 (Rabbit, } \\
\text { Thermo Scientific) } \\
\text { GLUT-1 (Mouse, } \\
\text { Thermo Scientific) } \\
\text { Occludin (Mouse, } \\
\text { Life Technologies) } \\
\text { CLAUDIN-5 } \\
\text { (Mouse, Life } \\
\text { Technologies) } \\
\text { VE-Cadherin } \\
\text { (Mouse, SCBT) } \\
\text { E-Cadherin (Goat, } \\
\text { R\&D Systems) } \\
\text { P-glycoprotein } \\
\text { (Mouse, Life } \\
\text { Technologies) } \\
\text { BCRP (Mouse, } \\
\text { Millipore) MRP1 } \\
\text { (Mouse, Millipore) } \\
\text { GFAP (Rabbit, } \\
\text { Dako) } \beta \text { Bll tubulin } \\
\text { (Rabbit, Sigma) } \\
\text { Nestin (Mouse, } \\
\text { Millipore) aSMA } \\
\text { (Mouse, American } \\
\text { Research Products) } \\
\text { PDGFR (Rabbit, } \\
\text { Cell Signaling) }\end{array}$ & $\begin{array}{l}\text { TEER, coculture } \\
\text { with NPC } \\
\text { astrocytes, neurons } \\
\text { and primary } \\
\text { pericytes }\end{array}$ & $\begin{array}{l}\text { DOXO, rhodamine } \\
\text { DCFDA }\end{array}$ \\
\hline
\end{tabular}


TABLE 1 | Continued

\begin{tabular}{|c|c|c|c|c|c|c|c|c|c|}
\hline Year & References & Protocol & Changes vs. 2012 & $\begin{array}{l}\text { Cell } \\
\text { line/Maintenance }\end{array}$ & $\begin{array}{l}\text { Differentiation } \\
\text { media }\end{array}$ & QPCR & Antibodies & Barrier assays & $\begin{array}{l}\text { Transporters/ } \\
\text { transcytosis }\end{array}$ \\
\hline 2017 & $\begin{array}{l}\text { Qian et al. (2017). } \\
\text { Science advances }\end{array}$ & $\begin{array}{l}6 \text { ( } \mu \text { M of CHIR on } \\
\text { DO-1, he medium } \\
\text { was removed and } \\
\text { cells were } \\
\text { transitioned to } \\
\text { DeSR2 (DeSR1 } \\
\text { plus B27 } \\
\text { supplement) for } \\
\text { another } 5 \text { days } \\
\text { with daily medium } \\
\text { changes. At day } 6 \text {, } \\
\text { cells were switched } \\
\text { to hECSR1 medium } \\
\text { [human endothelial } \\
\text { serum-free medium } \\
\text { (hESFM) } \\
\text { supplemented with } \\
\text { basic fibroblast } \\
\text { growth factor } \\
\text { (bFGF, } 20 \text { ng/ml), } \\
\text { 10 (M RA, and } \\
\text { B27] to induce RA } \\
\text { signaling in the } \\
\text { hPSC-derived } \\
\text { endothelial } \\
\text { progenitors in an } \\
\text { attempt to drive the } \\
\text { specification to } \\
\text { BMECs. Cells were } \\
\text { maintained in this } \\
\text { medium for } 2 \text { days. } \\
\text { At day } 8 \text {, cells were } \\
\text { replated onto a } \\
\text { Matrigel-coated } \\
\text { substrate in } \\
\text { hECSR1, and at } \\
\text { day 9, the medium } \\
\text { was switched to } \\
\text { hECSR2 (hECSR1 } \\
\text { lacking RA and } \\
\text { bFGF). }\end{array}$ & $\begin{array}{l}\text { Accutase instead of } \\
\text { Versene }\end{array}$ & $\begin{array}{l}\text { Human iPSCs } \\
\text { [iPS(IMR90)-4 (72), } \\
\text { iPS-DF 19-9-11T } \\
\text { (73), and hESCs } \\
\text { (H9) (29)] were } \\
\text { maintained on } \\
\text { Matrigel } \\
\text { (Corning)-coated } \\
\text { surfaces in mTeSR1 }\end{array}$ & $\begin{array}{l}6 \mu \text { M CHIR99021 } \\
\text { (Selleckchem) in } \\
\text { DeSR1: } \\
\text { DMEM/Ham's F12 } \\
\text { (Thermo Fisher } \\
\text { Scientific), } 1 \times \\
\text { MEM-NEAA } \\
\text { (Thermo Fisher } \\
\text { Scientific), 0.5× } \\
\text { GlutaMAX (Thermo } \\
\text { Fisher Scientific), } \\
\text { and 0.1 mM } \\
\beta \text {-mercaptoethanol } \\
\text { (Sigma). After 24 h, } \\
\text { the medium was } \\
\text { changed to DeSR2: } \\
\text { DeSR1 plus } 1 \times \\
\text { B27 (Thermo Fisher } \\
\text { Scientific) every day } \\
\text { for another } 5 \text { days. } \\
\text { At day 6, the } \\
\text { medium was } \\
\text { switched to } \\
\text { hECSR1: hESFM } \\
\text { (Thermo Fisher } \\
\text { Scientific) } \\
\text { supplemented with } \\
\text { bFGF (20 ng/ml), } \\
10 \mu M \text { RA, and } 1 \times \\
\text { B27 }\end{array}$ & & $\begin{array}{l}\text { Brachyury (R\&D } \\
\text { Systems) PAX2 } \\
\text { (SCBT) CD31 } \\
\text { (Thermo Fisher) } \\
\text { VE-Cadherin } \\
\text { (SCBT) vWF (Dako) } \\
\text { VEGFR2 (SCBT) } \\
\text { CLAUDIN-5 } \\
\text { (Invitrogen) } \\
\text { Occludin } \\
\text { (Invitrogen) ZO-1 } \\
\text { (Invitrogen) GLUT-1 } \\
\text { (Thermo Fisher) } \\
\text { PGP (Thermo } \\
\text { Fisher) BCRP } \\
\text { (Millipore) MRP1 } \\
\text { (Millipore) OCT3/4 } \\
\text { (SCBT) TRA-1-60 } \\
\text { (SCBT) NANOG } \\
\text { (SCBT) ICAM-1 } \\
\text { (R\&D Systems) }\end{array}$ & $\begin{array}{l}\text { "We also compared } \\
\text { the differentiation } \\
\text { reproducibility with } \\
\text { that of the } \\
\text { previously reported } \\
\text { UM protocol (33). } \\
\text { Although both } \\
\text { methods produce } \\
\text { BMECs capable of } \\
\text { substantial barrier } \\
\text { formation from } \\
\text { multiple hPSC lines, } \\
\text { BMECs } \\
\text { differentiated from } \\
\text { H9 hESCs and } \\
19-9-11 \text { iPSCs } \\
\text { using the defined } \\
\text { method exhibited } \\
\text { higher TEERs and } \\
\text { lower } \\
\text { batch-to-batch } \\
\text { variation." }\end{array}$ & $\begin{array}{l}\text { Efflux transporter } \\
\text { activities were } \\
\text { measured by the } \\
\text { intracellular } \\
\text { accumulation of (G) } \\
\text { rhodamine 123, (H) } \\
\text { Hoechst, and (I) } \\
\text { DCFDA, substrates } \\
\text { for Pgp, BCRP, and } \\
\text { MRP, respectively. } \\
\text { CsA, Ko143, and } \\
\text { MK571 were used } \\
\text { as specific } \\
\text { inhibitors of Pgp, } \\
\text { BCRP, and MRP, } \\
\text { respectively }\end{array}$ \\
\hline
\end{tabular}


TABLE 1 | Continued

\begin{tabular}{|c|c|c|c|c|c|c|c|c|c|}
\hline Year & References & Protocol & Changes vs. 2012 & $\begin{array}{l}\text { Cell } \\
\text { line/Maintenance }\end{array}$ & $\begin{array}{l}\text { Differentiation } \\
\text { media }\end{array}$ & QPCR & Antibodies & Barrier assays & $\begin{array}{l}\text { Transporters/ } \\
\text { transcytosis }\end{array}$ \\
\hline 2017 & $\begin{array}{l}\text { Hollmann et al. } \\
\text { (2017). Fluids } \\
\text { barriers CNS }\end{array}$ & $\begin{array}{l}\text { Modified } 2014 \\
\text { protocol }\end{array}$ & $\begin{array}{l}\text { E8 and E6 media, } \\
\text { E6 for } 4 \text { days then } \\
\text { continued as } \\
\text { Lippmann et al. } \\
\text { (2014) protocol. }\end{array}$ & $\begin{array}{l}\text { MR90-4 iPSCs } \\
\text { CC3 iPSCs, CD12 } \\
\text { iPSCs, and SM14 } \\
\text { iPSCs in growth } \\
\text { factor-reduced } \\
\text { Matrigel (VWR) in } \\
\text { E8 medium }\end{array}$ & $\begin{array}{l}\text { E8 medium was } \\
\text { prepared by adding } \\
100 \mu L \text { of human } \\
\text { insulin solution } \\
\text { (Sigma-Aldrich), } \\
500 \mu \mathrm{L} \text { of } \\
10 \mathrm{mg} / \mathrm{mL} \text { of } \\
\text { human } \\
\text { holo-transferrin } \\
\text { (R\&D Systems), } \\
500 \mu \mathrm{L} \text { of } \\
100 \mu \mathrm{g} / \mathrm{mL} \text { human } \\
\text { basic fibroblast } \\
\text { growth factor } \\
\text { (bFGF; PeproTech), } \\
\text { and } 500 \mu \mathrm{L} \text { of } \\
2 \mu \mathrm{g} / \mathrm{mL} \mathrm{TGF} \beta 1 \\
\text { (PeproTech) to } \\
500 \mathrm{~mL} \text { of } \mathrm{E} 4 \text {. The } \\
\text { final concentrations } \\
\text { are } 2.14 \mathrm{mg} / \mathrm{L} \\
\text { insulin, } 100 \mu \mathrm{g} / \mathrm{L} \\
\text { bFGF, } 2 \mu \mathrm{g} / \mathrm{L} \\
\text { TGF } \beta 1 \text {, and } \\
10.7 \mathrm{mg} / \mathrm{L} \\
\text { holo-transferrin E6 } \\
\text { medium was } \\
\text { prepared by adding } \\
100 \mu \mathrm{L} \text { of human } \\
\text { insulin solution and } \\
500 \mu \mathrm{L} \text { of } \\
10 \mathrm{mg} / \mathrm{mL} \text { of } \\
\text { human } \\
\text { holo-transferrin to } \\
500 \mathrm{~mL} \text { of } \mathrm{E} 4 \text {. The } \\
\text { final concentrations } \\
\text { are } 2.14 \mathrm{mg} / \mathrm{L} \\
\text { insulin and } \\
10.7 \mathrm{mg} / \mathrm{L} \\
\text { holo-transferrin UM } \\
\text { and } \mathrm{EC} \text { same as } \\
2-14\end{array}$ & & $\begin{array}{l}\text { PECAM-1 (Rabbit, } \\
\text { Thermo Scientific) } \\
\text { GLUT-1 (Mouse, } \\
\text { Thermo Scientific) } \\
\text { OCCLUDIN } \\
\text { (Mouse, Thermo } \\
\text { Scientific) } \\
\text { CLAUDIN-5 } \\
\text { (Mouse, Thermo } \\
\text { Scientific) } \\
\text { VE-Cadherin (Goat, } \\
\text { R\&D Systems) } \\
\text { GFAP (Rabbit, } \\
\text { Dako) PDGFR-B } \\
\text { (Rabbit, SCBT) } \\
\text { NG2 (Mouse, } \\
\text { SCBT) } \alpha \text { SMA } \\
\text { (Mouse, SCBT) }\end{array}$ & TEER & $\begin{array}{l}\text { Intracellular } \\
\text { accumulation of } \\
\text { rhodamine } 123 \text { (a } \\
\text { Pgp substrate) was } \\
\text { evaluated in the } \\
\text { absence of bFGF } \\
\text { and RA. Cells were } \\
\text { incubated with } \\
10 \mu \mathrm{M} \text { PSC } 833 \text { or } \\
10 \mu \mathrm{M} \text { MK-571 for } \\
1 \mathrm{~h} \text { at } 37^{\circ} \mathrm{C} \text {. They } \\
\text { were then } \\
\text { incubated for an } \\
\text { additional house } \\
\text { with } 10 \mu \mathrm{M} \\
\text { rhodamine } 123 \text { or } \\
10 \mu \mathrm{M} \text { H2DCFDA. }\end{array}$ \\
\hline
\end{tabular}

A summary of the original hPSC-derived iBMEC protocol (Lippmann et al., 2012) as well as the major adaptations made in subsequent studies (Lippmann et al., 2014; Hollmann et al., 2017; Qian et al., 2017) highlighting the key changes and experimental conditions used in each study. 
Delsing et al., 2018; Lee et al., 2018; Sances et al., 2018; Faley et al., 2019; Martins Gomes et al., 2019; Linville et al., 2020).

\section{CONFLICTING REPORTS OF IBMEC VASCULAR CELL IDENTITY}

Cellular identity is multifaceted and is usually determined by a combination of transcriptional, translational and functional phenotypes presented by a cell. This concept is particularly important for PSC-derived cell types, as directed differentiation to a target cell may yield a heterogenous population where the target cell type is less frequent or lacking in canonical lineage-specific genes that can have a tremendous impact on the overall efficacy of the cell as an in vitro model. Moreover, there is an existing concern regarding the standards by which cells engineered in vitro are validated against their primary counterparts in native tissues (Daley, 2015). These concerns stem from reports using only a small number of transcriptional or protein markers, limited or peripheral functional assays, and global RNA expression analyses which taken together can lead to a misguided identification of the cell type produced in vitro.

The characterization of iBMECs has been dominated by their in vitro barrier properties which has largely been based off the TEER measurements of these cells in monolayer conditions (Stebbins et al., 2016). Expression of barrier specific genes such as ZO-1 and OCLN have also served as a standard to bolster this barrier phenotype though these and many other tight junction marker genes expressed by iBMECs are not canonically specific to vascular ECs (Acharya et al., 2004; Hwang et al., 2013). Over time, some studies have started to present conflicting data regarding the cellular identity of these cells (Delsing et al., 2018; Lu et al., 2019; Vatine et al., 2019). Given that organ specific models rely heavily on cell specific responses to stimuli or cellcell interactions which can differ widely depending on cell type, concerns over iBMEC cellular identity presents a major problem with their use in in vitro BBB models.

As the BBB is principally a vascular structure, it is imperative that iBMECs are phenotypically, transcriptionally and functionally analogous to definitive ECs which make up the BBB. Recently, there have been several reports demonstrating certain incongruencies in the cellular identity of iBMECs. Delsing et al. (2018) demonstrated that iBMECs generated from the neuro-endothelial differentiation expressed a considerably lower level of key endothelial marker genes in both mono and coculture conditions when compared to other hPSC derived ECs or primary human BMECs. This study reported the presence of PECAM1, ZO-1, CLDN-5, VWF, and other endothelial markers in protein staining of iBMECs as well as hPSC derived ECs of a different protocol. However, the bulk RNA sequencing data reported a statistically significant decrease in mRNA expression of PECAM1, CDH5, CLDN5, and VWF, in iBMECs relative to the other ECs tested. The study went on to show that iBMECs express CLDN4, CLDN6, and CLDN7 indicating the presence of an epithelial cell junction. Taken together, this data led the group to conclude that iBMECs possess somewhat of a mixed phenotype (Delsing et al., 2018).
In $\mathrm{Lu}$ et al. (2019), our group conducted an in-depth characterization of iBMECs using a combinatorial analysis of protein and RNA expression comparing iBMECs from previously published work to their own. Our analysis also included multiple primary endothelial cell controls as well as hPSC derived ECs generated using a another previously published protocol (James et al., 2010). Initial microscopy and fluorescence activated cell sorting (FACS) revealed a lack of PECAM1 and CDH5 protein expression in iBMECs compared to the other ECs used in this study. EPCAM protein expression is also demonstrated in exclusively the iBMECs using the same assays. To validate these results, we performed a meta-analysis of bulk RNA sequencing data comparing their own iBMECs to previously published RNA transcriptomes obtained from the NCBI Gene Expression Omnibus (GEO).

We were able to demonstrate that not only were their iBMECs transcriptionally equivalent with previously published iBMECs but also that all iBMECs lacked a canonical EC transcriptional profile and conversely expressed many genes normally related to an epithelial cell lineage such as EPCAM, KRT8, KRT19, SPP1, and FREM2. These results were confirmed by single-cell RNA sequencing which also showed iBMECs to be a homogenous epithelial cell population lacking a vascular EC identity. An absence of key EC transcription factor (TF) and marker genes was observed in both RNA sequencing platforms, concerns over the validity of the previously established protein expression data becomes apparent. iBMECs used in this study were shown to be transcriptionally identical to those previously published which mean that positive protein expression data could be due to nonspecific binding by monoclonal antibodies, especially in the case of proteins from large homologous families such as Claudins (Krause et al., 2015). In summary, this study concludes that though iBMECs present a tight junction phenotype with high TEER, their cellular identity is severely lacking in congruency to vascular ECs making them unsuitable for use as an in vitro model of the human BBB (Lu et al., 2019) (Table 2).

TABLE 2 | hPSC-derived iBMECs are not phenotypically comparable to primary human BMECs.

\begin{tabular}{|c|c|c|}
\hline & $\begin{array}{l}\text { hPSC-Derived BMEC } \\
\text { in vitro }\end{array}$ & $\begin{array}{l}\text { Primary Human BMEC } \\
\text { in vitro }\end{array}$ \\
\hline $\begin{array}{l}\text { Surface marker } \\
\text { profile }\end{array}$ & $\begin{array}{l}\text { PECAM1 }^{-} \mathrm{CDH}^{-} \\
\mathrm{EPCAM}^{+}\end{array}$ & $\begin{array}{l}\mathrm{PECAM}^{+}{ }^{+} \mathrm{CDH}^{+} \\
\mathrm{EPCAM}^{-}\end{array}$ \\
\hline $\begin{array}{l}\text { Claudin family } \\
\text { repertoire }\end{array}$ & $\begin{array}{l}\text { Claudin-4, Claudin-6, } \\
\text { Claudin-7 }\end{array}$ & Claudin-5 \\
\hline $\begin{array}{l}\text { Barrier } \\
\text { properties }\end{array}$ & $\begin{array}{l}\text { High junctional electrical } \\
\text { resistance }\end{array}$ & $\begin{array}{l}\text { Low junctional electrical } \\
\text { resistance }\end{array}$ \\
\hline $\begin{array}{l}\text { Inflammatory } \\
\text { response }\end{array}$ & $\begin{array}{l}\text { No canonical vascular } \\
\text { response observed }\end{array}$ & $\begin{array}{l}\text { VCAM-1, ICAM-2, } \\
\text { E-Selectin upregulation }\end{array}$ \\
\hline $\begin{array}{l}\text { Significant } \\
\text { media } \\
\text { differences }\end{array}$ & $\begin{array}{l}\text { Serum free (or } 1 \% \text { platelet } \\
\text { poor bovine serum) }\end{array}$ & $\begin{array}{l}\text { Fetal bovine serum; } \\
\text { SB431542 }\end{array}$ \\
\hline $\begin{array}{l}\text { Extracellular } \\
\text { matrix }\end{array}$ & $\begin{array}{l}\text { Fibronectin/collagen IV } \\
\text { mixture }\end{array}$ & Gelatin \\
\hline
\end{tabular}

An overview of crucial differences between hPSC-derived iBMECs and primary human BMECs illustrating major differences in cellular phenotype as well as in vitro culture conditions. 
Using many of the same bulk RNA endothelial and epithelial control samples from the GEO repository as Lu et al. (2019), and their own iBMECs, Vatine et al. (2019) performed a meta-analysis as well. iBMECs in this study were seeded in an organ-chip device in which the authors claim they establish a hollow vessellike structure. A Principal Component Analysis (PCA) of their dataset revealed that iBMECs clustered closest to some of the endothelial controls. However, the lung epithelial cell libraries used in this analysis were prepared using total RNA without ribosomal depletion, while the rest of the dataset consisted of samples that were both polyA-primed and depleted of their ribosomal transcripts. Such a discrepancy in library preparation methods is likely to have caused a significant bias in this PCA; in fact, sample divergence across PC1 was exclusively due to the presence of ribosomal transcripts. Still, this meta-analysis also reported the presence of many epithelial cell transcripts in iBMEC samples, reinforcing previous conclusions about the presence of a non-vascular epithelial cell identity in these cells. This study goes on to introduce iBMEC organ-chips to different levels of laminar flow and co-culture with various hPSC-derived neural cell types. Bulk RNA sequencing of iBMECs in each of these conditions revealed a number of differences in expression of the CLDN gene family (Figure 1) as well as junction related genes (Figure 2) which the authors used to conclude that certain conditions allowed for the functional maturation of iBMECs (Vatine et al., 2019).

Importantly, these changes in expression levels were reported in relative terms for each transcript after normalization across samples that did not include an EC control. The FPKM values for some of the genes reported varied with statistical significance across conditions (CLDN4, CLDN6, HIF1A, and CAV1); however, some of these statistically significant differences denoted changes in FPKM values of less than 1 (CLDN5, CLDN10) stipulating an overall lack of function difference in gene expression. Interestingly, differences in FPKM values of greater than 20 occurs exclusively in genes more closely related to an epithelial lineage, reinforcing the notion of an epithelial phenotype in iBMECs. Differences in FPKM of some marker genes were also shown to be not significantly different between samples even though the Row $Z$-score demonstrates a large difference in expression. Moreover, the average FPKM of some of these marker genes across all samples was under 0.1 indicating that

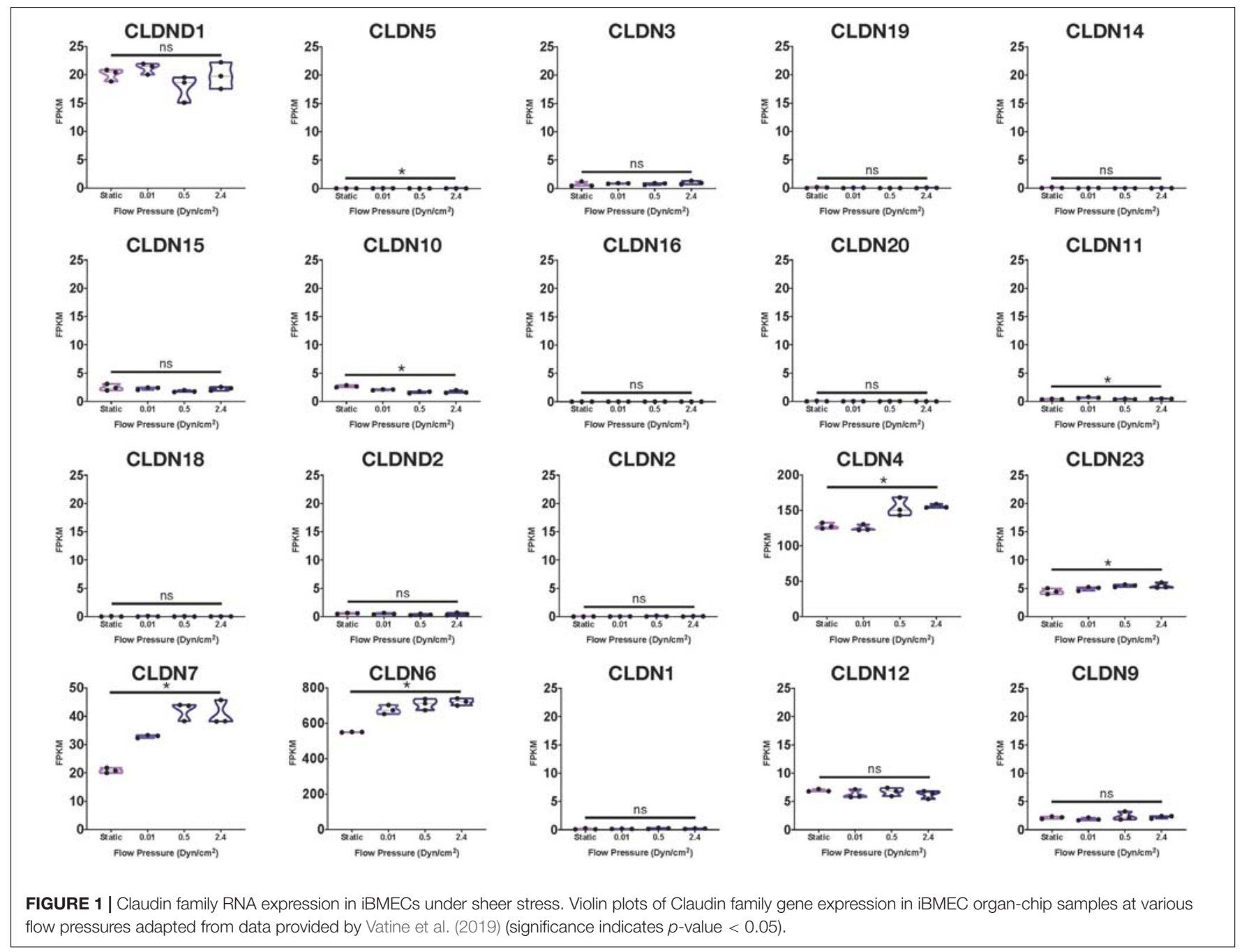




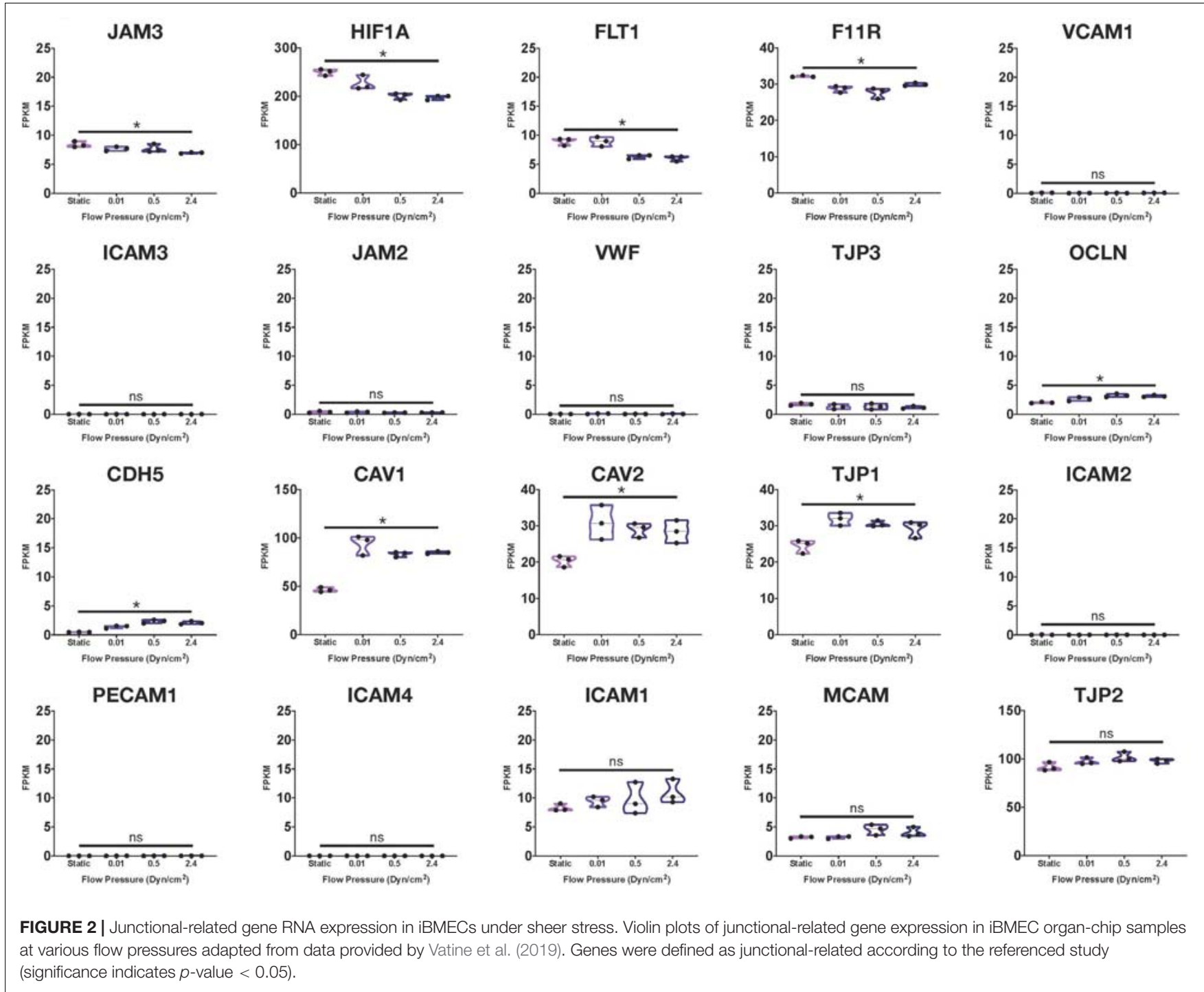

the genes are barely expressed and unlikely to undergo any translation (Hart et al., 2013). Interpretation of near zero FPKM values as functional expression of a gene could lead to incorrect assumptions of cell identity and functional phenotypes.

The lack of a functional vascular endothelial identity in iBMECs is further reinforced in a study by Martins Gomes et al. (2019) in their study focusing on their use as a disease model for Neisseria meningitidis $(\mathrm{Nm})$ infection of the brain. While characterizing the response of iBMECs to inflammatory factors brought on by $\mathrm{Nm}$ infection, the group notes no difference in VCAM-1 or E-Selectin RNA expression which shows a lack of an EC specific response to inflammatory stimuli. Nishihara et al. (2020) further bolsters these results with their study in which they assess immune cell interactions with iBMECs. They characterized the inflammatory response of iBMECs generated with the established method (Lippmann et al., 2014) and those generated using the later adapted chemically defined method (Qian et al., 2017). Interestingly, it was shown that iBMECs differentiated using either method did not stain positive for
ICAM-2, VCAM-1, E-selectin, or P-Selectin (Nishihara et al., 2020). ICAM-1 upregulation was only reported upon removal of retinoic acid, which was previously described to contribute greatly to the development of a vascular EC identity in these cells (Lippmann et al., 2014), from the differentiation process. The group ultimately concluded that iBMECs generated from any of these protocols lack expression of many vascular cell adhesion molecules and are not well suited for modeling immune cell interactions in the BBB.

\section{POSSIBLE MEANS FOR INDUCTION OF VASCULAR BBB PHENOTYPE IN HPSC-DERIVED CELLS IN VITRO}

Before a functional hPSC-derived vascular BBB model can be developed, stable hPSC-derived vascular ECs must be generated. In a recent study (Lu et al., 2021), our group demonstrated that a vascular fate can be induced in iBMECs through 
introduction of certain EC-specific ETS TFs (ETV2, ERG, and FLI1). These reprogrammed cells (rECs) harbor an EC transcriptomic profile, retaining a $\mathrm{PECAM} 1^{+} \mathrm{CDH} 5^{+} \mathrm{KDR}^{+} \mathrm{EC}$ immunophenotype during passaging and expansion. Purified rECs can respond to inflammatory stimuli (i.e., TNF- $\alpha$ ) and permeabilizing agents (i.e., VEGF-A and anti-VE-cadherin antibody) in a manner congruent with vascular ECs. rECs were also shown to be capable of forming tubes in vivo using an immunocompromised mouse model, whereas iBMECs derived from the same hPSCs could not. This strategy of transcription factor reprogramming establishes a vascular EC identity in cells that otherwise lacked any phenotypic and functional aspects of bona fide ECs. However, further work is required to generate a reliable brain specific EC and that this only represents a crucial step toward the generation of true brain ECs suitable for in vitro modeling of physiological and pharmaceutical studies of the BBB.

In addition to the co-culture systems referenced above, numerous culture conditions have been demonstrated to improve $\mathrm{BBB}$ phenotypes in vitro. Some groups were able to show that neural cell conditioned media could increase barrier resistance and decrease permeability in BMEC monolayers (Siddharthan et al., 2007; Puech et al., 2018). Others have used cytokines and small molecules in the culture medium to modify barrier and vascular phenotypes these ECs. As previously mentioned, de Vries et al. (1996) demonstrated that exposure to cytokines such as TNF- $\alpha$, IL1- $\beta$, and IL- 6 induces an overall decline in TEER across rat brain EC monolayers. Schulze et al. (1997) later showed that Lysophosphatidic Acid increases tight junction permeability in porcine brain ECs. In contrast, a study from Roudnicky et al. (2020b) has indicated that the ALK5 inhibitor RepSox could modulate EC barrier stability. These studies all support the notion that microenvironmental queues play a large role in the homeostatic regulation of BMECs and adjustments to culture conditions will largely affect the overall function of an in vitro $\mathrm{BBB}$ model.

Moving on from culture conditions, intrinsic transcriptional regulation may also be critical for the establishment of a vascular BBB model. A separate Roudnicky et al. (2020a) study was able to demonstrate that synergistic overexpression of TFs including SOX18, TAL1, SOX7, and ETS1 can enhance certain properties in EC such as barrier function. Their work shows that hPSC-derived ECs transduced with these TFs have increased transmembrane electrical resistance and tight junction protein expression while also decreasing paracellular transport (Roudnicky et al., 2020a). Taken together, this data suggests transcription factor overexpression could eventually be used in conjunction with chemomodulation in order to directly generate

\section{Endothelial Cell}
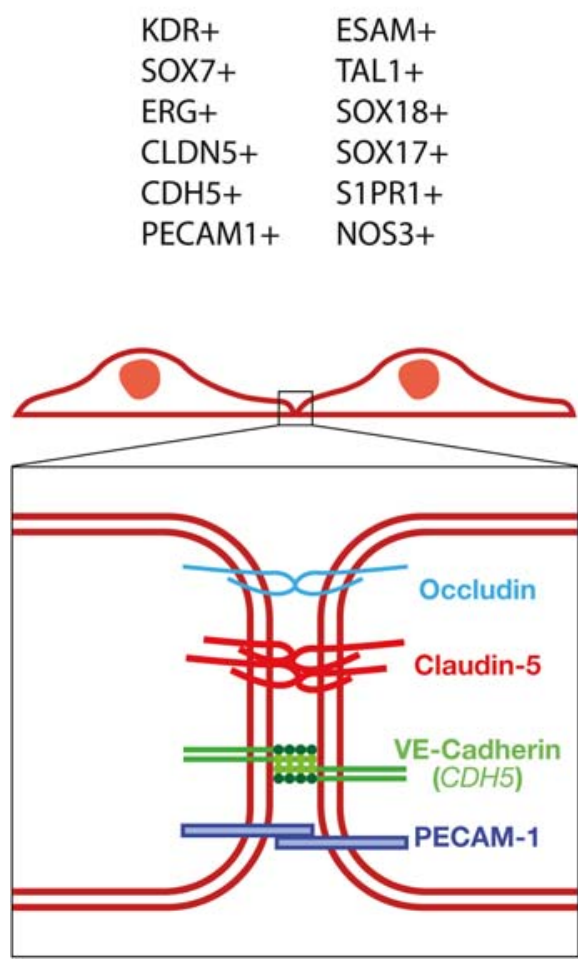

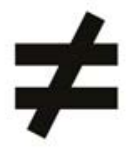

IBMEC

$\begin{array}{ll}\text { FREM2+ } & \text { TRPV6+ } \\ \text { SPP1+ } & \text { ERBB3+ } \\ \text { KRT8+ } & \text { ELF3+ } \\ \text { CLDN4+ } & \text { ESRP1+ } \\ \text { CDH1+ } & \text { CDH3+ } \\ \text { EPCAM+ } & \text { CLDN6+ }\end{array}$

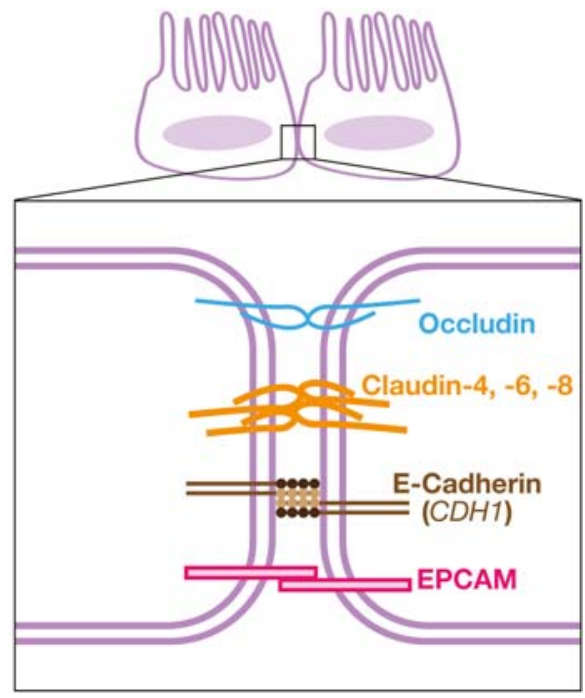

FIGURE 3 | iBMECs do not possess an endothelial transcriptional profile or vascular junctional components. iBMECs are shown to lack expression of phenotypical markers of a vascular EC lineage while expressing many epithelial cell lineage genes by bulk and single-cell RNA sequencing methods. The junctional components in iBMECs are also incongruent with canonical EC junctions leading to very serious concerns as to the efficacy of their use in an in vitro vascular BBB model. 
brain-specific ECs from hPSCs which could be suitable for in vitro $\mathrm{BBB}$ models.

\section{CONCLUDING REMARKS}

Over the past decade many groups have aimed to advance the study of the $\mathrm{BBB}$ by developing in vitro models attempting to mimic the physiological complexity of the $\mathrm{BBB}$ in vivo. Many difficulties have arisen during the course of these efforts as such models must phenocopy the high TEER observed in vivo as well as the intricate cellular transport mechanisms that are hallmarks of the BBB. It has been demonstrated that $\mathrm{BBB}$ traits are not intrinsic to brain specific ECs, but rather the result of a dynamic interplay with their microenvironment including multiple cell types such as astrocytes and pericytes. Consequently, primary brain ECs lose their barrier properties, especially high TEER, when cultured in vitro. Many laboratories have attempted to resolve this issue by developing various in vitro $\mathrm{BBB}$ models using neural cell co-cultures consisting of ECs, pericytes, and astrocytes. These models also include pluripotent stem cell differentiation methods as well as brain organoids and 'organ-ona-chip' approaches.

Validation of these in vitro models relies mainly on using TEER and expression of tight junction proteins as a determinant of barrier function. Using these measurements as a proxy for functional BBB-specific tight junctions presents some limitations since it can only measure the paracellular junctions. The BBB has many transcellular permeability functions that are imperative for its function which cannot be measured in this way. Additionally, high TEER and many of the junctional proteins used to validate brain EC identity have been demonstrated in other nonendothelial cell types such as epithelial cells. ECs have also been shown to possess a polarized morphology (Lizama and Zovein, 2013) similar to epithelial cells, however, these morphological and junctional characteristics do not suggest that epithelial cells can be used interchangeably with ECs in in vitro vascular barrier models. Other problems may also have arisen from assigning a vascular EC identity to hPSC-derived cells based on the expression of a restricted set of brain EC markers. False positive results of EC identity can occur in these cases due to antibody cross-reactivity with proteins present in the cell sample that are not specific to ECs. As shown, iBMECs may demonstrate

\section{REFERENCES}

Abbott, N. J., Dolman, D. E., Drndarski, S., and Fredriksson, S. M. (2012). An improved in vitro blood-brain barrier model: rat brain endothelial cells co-cultured with astrocytes. Methods Mol. Biol. 814, 415-430.

Acharya, P., Beckel, J., Ruiz, W. G., Wang, E., Rojas, R., Birder, L., et al. (2004). Distribution of the tight junction proteins ZO-1, occludin, and claudin-4, -8, and -12 in bladder epithelium. Am. J. Physiol. Renal. Physiol. 287, F305-F318. doi: 10.1152/ajprenal.00341.2003

Aird, W. C. (2007a). Phenotypic heterogeneity of the endothelium: I. Structure, function, and mechanisms. Circ. Res. 100, 158-173.

Aird, W. C. (2007b). Phenotypic heterogeneity of the endothelium: II. Representative vascular beds. Circ. Res. 100, 174-190. doi: 10.1161/01.RES. 0000255690.03436.ae a high TEER in vitro and express certain non-vascular specific junctional genes, however, they lack many functional phenotypes intrinsic to ECs. By not responding to inflammatory stimuli in an EC specific manner, their use in many models would yield results misrepresenting the in vivo $\mathrm{BBB}$ (Figure 3).

Taken altogether, the data presented by recent studies (Delsing et al., 2018; Lu et al., 2019; Martins Gomes et al., 2019; Vatine et al., 2019; Nishihara et al., 2020) contradict the vascular cellular identity of iBMECs and instead demonstrate that these cells might be of an epithelial lineage. iBMECs have been shown to lack expression of key EC marker genes such as PECAM1, CDH5, CLDN5, and VWF while also expressing epithelial cell genes including EPCAM, FREM2, and CLDN4. Expression of genes such as E-Selectin, VCAM-1, P-Selectin were also shown to be completely unaffected by inflammatory stimuli further decreasing the possibility for these cells to be used as a functional model of the $\mathrm{BBB}$ in vitro. This leads to the possibility that the barrier function observed in iBMECs could in fact more closely resemble an epithelial cell barrier such as the choroid plexus or intestinal epithelial barrier. As these cells lack a canonical vascular EC phenotype, the use of current protocols to generate iBMECs as prototypical human BBB model could results in inaccurate physiological studies and screening for misguided druggable targets or treatments with potential ineffective clinical outcomes. Thus, the application of a rigorous and thorough characterization of stem cell-derived products using the latest available technologies such as single cell multi-omics and metabolomics should be necessary, rather than facultative, for the development of faithful disease models and safe cell-based therapies.

\section{DATA AVAILABILITY STATEMENT}

The original contributions generated for this study are included in the article/supplementary material, further inquiries can be directed to the corresponding authors.

\section{AUTHOR CONTRIBUTIONS}

All authors listed have made a substantial, direct and intellectual contribution to the work, and approved it for publication.

Alvarez, J. I., Dodelet-Devillers, A., Kebir, H., Ifergan, I., Fabre, P. J., Terouz, S., et al. (2011). The Hedgehog pathway promotes blood-brain barrier integrity and CNS immune quiescence. Science 334, 1727-1731. doi: 10.1126/science. 1206936

Andaloussi Mae, M., He, L., Nordling, S., Vazquez-Liebanas, E., Nahar, K., Jung, B., et al. (2020). Single-cell analysis of blood-brain barrier response to pericyte loss. Circ. Res. 128, e46-e62. doi: 10.1161/CIRCRESAHA.120.31 7473

Anderson, K. D., Pan, L., Yang, X.-m, Hughes, V. C., Walls, J. R., Dominguez, M. G., et al. (2011). Angiogenic sprouting into neural tissue requires Gpr124, an orphan G protein-coupled receptor. Proc. Natl. Acad. Sci. U.S.A. 108, 2807-2812. doi: 10.1073/pnas.1019761108

Appelt-Menzel, A., Cubukova, A., Günther, K., Edenhofer, F., Piontek, J., Krause, G., et al. (2017). Establishment of a human blood-brain barrier co-culture model 
mimicking the neurovascular unit using induced pluri- and multipotent stem cells. Stem Cell Rep. 8, 894-906. doi: 10.1016/j.stemcr.2017.02.021

Armulik, A., Genove, G., Mae, M., Nisancioglu, M. H., Wallgard, E., Niaudet, C., et al. (2010). Pericytes regulate the blood-brain barrier. Nature 468, 557-561. doi: 10.1038 /nature 09522

Bär, T. (1980). The vascular system of the cerebral cortex. Adv. Anat. Embryol. Cell Biol. 59, I-VI, 1-62. doi: 10.1007/978-3-642-67432-7

Bell, R. D., Winkler, E. A., Sagare, A. P., Singh, I., LaRue, B., Deane, R., et al. (2010). Pericytes control key neurovascular functions and neuronal phenotype in the adult brain and during brain aging. Neuron $68,409-427$. doi: 10.1016/j.neuron. 2010.09.043

Ben-Zvi, A., Lacoste, B., Kur, E., Andreone, B. J., Mayshar, Y., Yan, H., et al. (2014). Mfsd2a is critical for the formation and function of the blood-brain barrier. Nature 509, 507-511. doi: 10.1038/nature13324

Bernas, M. J., Cardoso, F. L., Daley, S. K., Weinand, M. E., Campos, A. R., Ferreira, A. J., et al. (2010). Establishment of primary cultures of human brain microvascular endothelial cells to provide an in vitro cellular model of the blood-brain barrier. Nat. Protoc. 5, 1265-1272. doi: 10.1038/nprot.2010.76

Bohara, M., Kambe, Y., Nagayama, T., Tokimura, H., Arita, K., and Miyata, A. (2014). C-type natriuretic peptide modulates permeability of the blood-brain barrier. J. Cereb. Blood Flow Metab. 34, 589-596. doi: 10.1038/jcbfm.2013.234

Boveri, M., Kinsner, A., Berezowski, V., Lenfant, A. M., Draing, C., Cecchelli, R., et al. (2006). Highly purified lipoteichoic acid from gram-positive bacteria induces in vitro blood-brain barrier disruption through glia activation: role of pro-inflammatory cytokines and nitric oxide. Neuroscience 137, 1193-1209. doi: 10.1016/j.neuroscience.2005.10.011

Brightman, M. W., and Reese, T. S. (1969). Junctions between intimately apposed cell membranes in the vertebrate brain. J. Cell Biol. 40, 648-677.

Burek, M., Salvador, E., and Förster, C. Y. (2012). Generation of an immortalized murine brain microvascular endothelial cell line as an in vitro blood brain barrier model. J. Vis. Exp. 66:e4022. doi: 10.3791/4022

Calabria, A. R., Weidenfeller, C., Jones, A. R., de Vries, H. E., and Shusta, E. V. (2006). Puromycin-purified rat brain microvascular endothelial cell cultures exhibit improved barrier properties in response to glucocorticoid induction. J. Neurochem. 97, 922-933. doi: 10.1111/j.1471-4159.2006.03793.x

Canfield, S. G., Stebbins, M. J., Morales, B. S., Asai, S. W., Vatine, G. D., Svendsen, C. N., et al. (2017). An isogenic blood-brain barrier model comprising brain endothelial cells, astrocytes and neurons derived from human induced pluripotent stem cells. J. Neurochem. 140, 874-888. doi: 10.1111/jnc.13923

Castro Dias, M., Coisne, C., Lazarevic, I., Baden, P., Hata, M., Iwamoto, N., et al. (2019). Claudin-3-deficient C57BL/6 J mice display intact brain barriers. Sci. Rep. 9:203. doi: 10.1038/s41598-018-36731-3

Cecchelli, R., Berezowski, V., Lundquist, S., Culot, M., Renftel, M., Dehouck, M. P., et al. (2007). Modelling of the blood-brain barrier in drug discovery and development. Nat. Rev. Drug Discov. 6, 650-661. doi: 10.1038/nrd2368

Cohen-Kashi Malina, K., Cooper, I., and Teichberg, V. I. (2009). Closing the gap between the in-vivo and in-vitro blood-brain barrier tightness. Brain Res. 1284, 12-21. doi: 10.1016/j.brainres.2009.05.072

Coisne, C., Dehouck, L., Faveeuw, C., Delplace, Y., Miller, F., Landry, C., et al. (2005). Mouse syngenic in vitro blood-brain barrier model: a new tool to examine inflammatory events in cerebral endothelium. Lab. Invest. 85, 734-746. doi: 10.1038/labinvest.3700281

Cullen, M., Elzarrad, M. K., Seaman, S., Zudaire, E., Stevens, J., Yang, M. Y., et al. (2011). GPR124, an orphan G protein-coupled receptor, is required for CNSspecific vascularization and establishment of the blood-brain barrier. Proc. Natl. Acad. Sci. U.S.A. 108:5759. doi: 10.1073/pnas. 1017192108

Daley, G. Q. (2015). Stem cells and the evolving notion of cellular identity. Philos. Trans. R. Soc. Lond. B Biol. Sci. 370:20140376. doi: 10.1098/rstb.2014.0376

Daneman, R. (2012). The blood-brain barrier in health and disease. Ann. Neurol. 72, 648-672. doi: 10.1002/ana.23648

Daneman, R., Agalliu, D., Zhou, L., Kuhnert, F., Kuo, C. J., and Barres, B. A. (2009). $\mathrm{Wnt} / \beta$-catenin signaling is required for CNS, but not non-CNS, angiogenesis. Proc. Natl. Acad. Sci. U.S.A. 106, 641-646. doi: 10.1073/pnas.0805165106

Daneman, R., and Prat, A. (2015). The blood-brain barrier. Cold Spring Harb. Perspect. Biol. 7:a020412. doi: 10.1101/cshperspect.a020412

Daneman, R., Zhou, L., Kebede, A. A., and Barres, B. A. (2010). Pericytes are required for blood-brain barrier integrity during embryogenesis. Nature 468, 562-566. doi: 10.1038/nature09513 de Vries, H. E., Blom-Roosemalen, M. C., van Oosten, M., de Boer, A. G., van Berkel, T. J., Breimer, D. D., et al. (1996). The influence of cytokines on the integrity of the blood-brain barrier in vitro. J. Neuroimmunol. 64, 37-43. doi: 10.1016/0165-5728(95)00148-4

Dehouck, M. P., Méresse, S., Delorme, P., Fruchart, J. C., and Cecchelli, R. (1990). An easier, reproducible, and mass-production method to study the blood-brain barrier in vitro. J. Neurochem. 54, 1798-1801. doi: 10.1111/j.1471-4159.1990. tb01236.x

Deli, M. A., Abrahám, C. S., Kataoka, Y., and Niwa, M. (2005). Permeability studies on in vitro blood-brain barrier models: physiology, pathology, and pharmacology. Cell. Mol. Neurobiol. 25, 59-127. doi: 10.1007/s10571-0041377-8

Delsing, L., Donnes, P., Sanchez, J., Clausen, M., Voulgaris, D., Falk, A., et al. (2018). Barrier properties and transcriptome expression in human iPSCderived models of the blood-brain barrier. Stem Cells 36, 1816-1827. doi: 10. 1002/stem. 2908

DeStefano, J. G., Xu, Z. S., Williams, A. J., Yimam, N., and Searson, P. C. (2017). Effect of shear stress on iPSC-derived human brain microvascular endothelial cells (dhBMECs). Fluids Barriers CNS 14:20. doi: 10.1186/s12987-017-0068-z

Engelhardt, B. (2003). Development of the blood-brain barrier. Cell Tissue Res. 314, 119-129. doi: 10.1007/s00441-003-0751-z

Faley, S. L., Neal, E. H., Wang, J. X., Bosworth, A. M., Weber, C. M., Balotin, K. M., et al. (2019). iPSC-derived brain endothelium exhibits stable, long-term barrier function in perfused hydrogel scaffolds. Stem Cell Rep. 12, 474-487. doi: 10.1016/j.stemcr.2019.01.009

Gaillard, P. J., and de Boer, A. G. (2000). Relationship between permeability status of the blood-brain barrier and in vitro permeability coefficient of a drug. Eur. J. Pharm. Sci. 12, 95-102. doi: 10.1016/s0928-0987(00)00152-4

Gaillard, P. J., Voorwinden, L. H., Nielsen, J. L., Ivanov, A., Atsumi, R., Engman, H., et al. (2001). Establishment and functional characterization of an in vitro model of the blood-brain barrier, comprising a co-culture of brain capillary endothelial cells and astrocytes. Eur. J. Pharm. Sci. 12, 215-222. doi: 10.1016/ s0928-0987(00)00123-8

Garberg, P., Ball, M., Borg, N., Cecchelli, R., Fenart, L., Hurst, R. D., et al. (2005). In vitro models for the blood-brain barrier. Toxicol. In Vitro 19, 299-334. doi: 10.1016/j.tiv.2004.06.011

Hariharan, A., Weir, N., Robertson, C., He, L., Betsholtz, C., and Longden, T. A. (2020). The ion channel and GPCR toolkit of brain capillary pericytes. Front. Cell. Neurosci. 14:601324. doi: 10.3389/fncel.2020.601324

Hart, T., Komori, H. K., LaMere, S., Podshivalova, K., and Salomon, D. R. (2013). Finding the active genes in deep RNA-seq gene expression studies. BMC Genomics 14:778. doi: 10.1186/1471-2164-14-778

Helms, H. C., Abbott, N. J., Burek, M., Cecchelli, R., Couraud, P.-O., Deli, M. A., et al. (2016). In vitro models of the blood-brain barrier: an overview of commonly used brain endothelial cell culture models and guidelines for their use. J. Cereb. Blood Flow Metab. 36, 862-890. doi: 10.1177/0271678X16630991

Helms, H. C., Hersom, M., Kuhlmann, L. B., Badolo, L., Nielsen, C. U., and Brodin, B. (2014). An electrically tight in vitro blood-brain barrier model displays net brain-to-blood efflux of substrates for the $\mathrm{ABC}$ transporters, P-gp, Bcrp and Mrp-1. AAPS J. 16, 1046-1055. doi: 10.1208/s12248-014-9628-1

Helms, H. C., Madelung, R., Waagepetersen, H. S., Nielsen, C. U., and Brodin, B. (2012). In vitro evidence for the brain glutamate efflux hypothesis: brain endothelial cells cocultured with astrocytes display a polarized brain-to-blood transport of glutamate. Glia 60, 882-893. doi: 10.1002/glia.22321

Helms, H. C., Waagepetersen, H. S., Nielsen, C. U., and Brodin, B. (2010). Paracellular tightness and claudin-5 expression is increased in the BCEC/astrocyte blood-brain barrier model by increasing media buffer capacity during growth. AAPS J. 12, 759-770. doi: 10.1208/s12248-010-9237-6

Hollmann, E. K., Bailey, A. K., Potharazu, A. V., Neely, M. D., Bowman, A. B., and Lippmann, E. S. (2017). Accelerated differentiation of human induced pluripotent stem cells to blood-brain barrier endothelial cells. Fluids Barriers CNS 14:9. doi: 10.1186/s12987-017-0059-0

Hoshi, Y., Uchida, Y., Tachikawa, M., Inoue, T., Ohtsuki, S., and Terasaki, T. (2013). Quantitative atlas of blood-brain barrier transporters, receptors, and tight junction proteins in rats and common marmoset. J. Pharm. Sci. 102, 3343-3355. doi: 10.1002/jps.23575

Hwang, I., An, B. S., Yang, H., Kang, H. S., Jung, E. M., and Jeung, E. B. (2013). Tissue-specific expression of occludin, zona occludens-1, and junction adhesion 
molecule $\mathrm{A}$ in the duodenum, ileum, colon, kidney, liver, lung, brain, and skeletal muscle of C57BL mice. J. Physiol. Pharmacol. 64, 11-18.

James, D., Nam, H.-s, Seandel, M., Nolan, D., Janovitz, T., Tomishima, M., et al. (2010). Expansion and maintenance of human embryonic stem cell-derived endothelial cells by TGF $\beta$ inhibition is Id1 dependent. Nat. Biotechnol. 28:161. doi: $10.1038 /$ nbt. 1605

Kisucka, J., Chauhan, A. K., Zhao, B.-Q., Patten, I. S., Yesilaltay, A., Krieger, M., et al. (2009). Elevated levels of soluble P-selectin in mice alter blood-brain barrier function, exacerbate stroke, and promote atherosclerosis. Blood 113, 6015-6022. doi: 10.1182/blood-2008-10-186650

Kitagawa, K., Matsumoto, M., Mabuchi, T., Yagita, Y., Ohtsuki, T., Hori, M., et al. (1998). Deficiency of intercellular adhesion molecule 1 attenuates microcirculatory disturbance and infarction size in focal cerebral ischemia. J. Cereb. Blood Flow Metab. 18, 1336-1345. doi: 10.1097/00004647-19981200000008

Kominsky, S. L., Tyler, B., Sosnowski, J., Brady, K., Doucet, M., Nell, D., et al. (2007). Clostridium perfringens enterotoxin as a novel-targeted therapeutic for brain metastasis. Cancer Res. 67, 7977-7982. doi: 10.1158/0008-5472.CAN-071314

Krause, G., Protze, J., and Piontek, J. (2015). Assembly and function of claudins: structure-function relationships based on homology models and crystal structures. Semin. Cell Dev. Biol. 42, 3-12. doi: 10.1016/j.semcdb.2015.04.010

Kuhnert, F., Mancuso, M. R., Shamloo, A., Wang, H.-T., Choksi, V., Florek, M., et al. (2010). Essential regulation of CNS angiogenesis by the orphan G protein-coupled receptor GPR124. Science 330, 985-989. doi: 10.1126/science. 1196554

Lee, C. A. A., Seo, H. S., Armien, A. G., Bates, F. S., Tolar, J., and Azarin, S. M. (2018). Modeling and rescue of defective blood-brain barrier function of induced brain microvascular endothelial cells from childhood cerebral adrenoleukodystrophy patients. Fluids Barriers CNS 15:9. doi: 10.1186/s12987018-0094-5

Liebner, S., Fischmann, A., Rascher, G., Duffner, F., Grote, E. H., Kalbacher, H., et al. (2000). Claudin-1 and claudin-5 expression and tight junction morphology are altered in blood vessels of human glioblastoma multiforme. Acta Neuropathol. 100, 323-331. doi: 10.1007/s004010000180

Lim, R. G., Quan, C., Reyes-Ortiz, A. M., Lutz, S. E., Kedaigle, A. J., Gipson, T. A., et al. (2017). Huntington's disease iPSC-derived brain microvascular endothelial cells reveal WNT-mediated angiogenic and blood-brain barrier deficits. Cell Rep. 19, 1365-1377. doi: 10.1016/j.celrep.2017.04.021

Linville, R. M., DeStefano, J. G., Nerenberg, R. F., Grifno, G. N., Ye, R., Gallagher, E., et al. (2020). Long-term cryopreservation preserves blood-brain barrier phenotype of iPSC-derived brain microvascular endothelial cells and three-dimensional microvessels. Mol. Pharm. 17, 3425-3434. doi: 10.1021/acs. molpharmaceut.0c00484

Lippmann, E. S., Al-Ahmad, A., Azarin, S. M., Palecek, S. P., and Shusta, E. V. (2014). A retinoic acid-enhanced, multicellular human blood-brain barrier model derived from stem cell sources. Sci. Rep. 4:4160. doi: 10.1038/srep04160

Lippmann, E. S., Al-Ahmad, A., Palecek, S. P., and Shusta, E. V. (2013). Modeling the blood-brain barrier using stem cell sources. Fluids Barriers CNS 10:2. doi: 10.1186/2045-8118-10-2

Lippmann, E. S., Azarin, S. M., Kay, J. E., Nessler, R. A., Wilson, H. K., Al-Ahmad, A., et al. (2012). Derivation of blood-brain barrier endothelial cells from human pluripotent stem cells. Nat. Biotechnol. 30:783. doi: 10.1038/nbt.2247

Liu, H., Li, Y., Lu, S., Wu, Y., and Sahi, J. (2014). Temporal expression of transporters and receptors in a rat primary co-culture blood-brain barrier model. Xenobiotica 44, 941-951. doi: 10.3109/00498254.2014.919430

Lizama, C. O., and Zovein, A. C. (2013). Polarizing pathways: balancing endothelial polarity, permeability, and lumen formation. Exp. Cell Res. 319, 1247-1254. doi: 10.1016/j.yexcr.2013.03.028

Lu, T. M., Houghton, S., Magdeldin, T., Durán, J. G. B., Minotti, A. P., Snead, A., et al. (2021). Pluripotent stem cell-derived epithelium misidentified as brain microvascular endothelium requires ETS factors to acquire vascular fate. Proc Natl. Acad. Sci. U.S.A. 118:e2016950118. doi: 10.1073/pnas.2016950118

Lu, T. M., Redmond, D., Magdeldin, T., Nguyen, D.-H. T., Snead, A., Sproul, A., et al. (2019). Human induced pluripotent stem cell-derived neuroectodermal epithelial cells mistaken for blood-brain barrier-forming endothelial cells. bioRxiv [Preprint]. doi: 10.1101/699173 bioRxiv: 699173,
Ma, X. J., Cheng, J. W., Zhang, J., Liu, A. J., Liu, W., Guo, W., et al. (2012). Eselectin deficiency attenuates brain ischemia in mice. CNS Neurosci. Ther. 18, 903-908. doi: 10.1111/cns. 12000

Martins Gomes, S. F., Westermann, A. J., Sauerwein, T., Hertlein, T., Forstner, K. U., Ohlsen, K., et al. (2019). Induced pluripotent stem cell-derived brain endothelial cells as a cellular model to study Neisseria meningitidis infection. Front. Microbiol. 10:1181. doi: 10.3389/fmicb.2019.01181

Nakagawa, S., Deli, M. A., Kawaguchi, H., Shimizudani, T., Shimono, T., Kittel, A., et al. (2009). A new blood-brain barrier model using primary rat brain endothelial cells, pericytes and astrocytes. Neurochem. Int. 54, 253-263. doi: 10.1016/j.neuint.2008.12.002

Nakagawa, S., Deli, M. A., Nakao, S., Honda, M., Hayashi, K., Nakaoke, R., et al. (2007). Pericytes from brain microvessels strengthen the barrier integrity in primary cultures of rat brain endothelial cells. Cell. Mol. Neurobiol. 27, 687-694. doi: 10.1007/s10571-007-9195-4

Neal, E. H., Marinelli, N. A., Shi, Y., McClatchey, P. M., Balotin, K. M., Gullett, D. R., et al. (2019). A simplified, fully defined differentiation scheme for producing blood-brain barrier endothelial cells from human iPSCs. Stem Cell Rep. 12, 1380-1388. doi: 10.1016/j.stemcr.2019.05.008

Nishihara, H., Gastfriend, B. D., Soldati, S., Perriot, S., Mathias, A., Sano, Y., et al. (2020). Advancing human induced pluripotent stem cell-derived bloodbrain barrier models for studying immune cell interactions. FASEB J. 34, 16693-16715. doi: 10.1096/fj.202001507RR

Obermeier, B., Daneman, R., and Ransohoff, R. M. (2013). Development, maintenance and disruption of the blood-brain barrier. Nat. Med. 19, 15841596. doi: $10.1038 / \mathrm{nm} .3407$

Patabendige, A., Skinner, R. A., Morgan, L., and Abbott, N. J. (2013). A detailed method for preparation of a functional and flexible blood-brain barrier model using porcine brain endothelial cells. Brain Res. 1521, 16-30. doi: 10.1016/j. brainres.2013.04.006

Perrière, N., Demeuse, P., Garcia, E., Regina, A., Debray, M., Andreux, J. P., et al. (2005). Puromycin-based purification of rat brain capillary endothelial cell cultures. Effect on the expression of blood-brain barrier-specific properties. J. Neurochem. 93, 279-289. doi: 10.1111/j.1471-4159.2004.03020.x

Pfeiffer, F., Schafer, J., Lyck, R., Makrides, V., Brunner, S., Schaeren-Wiemers, N., et al. (2011). Claudin-1 induced sealing of blood-brain barrier tight junctions ameliorates chronic experimental autoimmune encephalomyelitis. Acta Neuropathol. 122, 601-614. doi: 10.1007/s00401-011-0883-2

Piontek, J., Winkler, L., Wolburg, H., Muller, S. L., Zuleger, N., Piehl, C., et al. (2008). Formation of tight junction: determinants of homophilic interaction between classic claudins. FASEB J. 22, 146-158. doi: 10.1096/ff.07-8319com

Potente, M., Gerhardt, H., and Carmeliet, P. (2011). Basic and therapeutic aspects of angiogenesis. Cell 146, 873-887. doi: 10.1016/j.cell.2011.08.039

Puech, C., Hodin, S., Forest, V., He, Z., Mismetti, P., Delavenne, X., et al. (2018). Assessment of HBEC-5i endothelial cell line cultivated in astrocyte conditioned medium as a human blood-brain barrier model for $\mathrm{ABC}$ drug transport studies. Int. J. Pharm. 551, 281-289. doi: 10.1016/j.ijpharm.2018.09.040

Qian, T., Maguire, S. E., Canfield, S. G., Bao, X., Olson, W. R., Shusta, E. V., et al. (2017). Directed differentiation of human pluripotent stem cells to blood-brain barrier endothelial cells. Sci. Adv. 3:e1701679. doi: 10.1126/sciadv.1701679

Rahman, N. A., Rasil, A. N. H. M., Meyding-Lamade, U., Craemer, E. M., Diah, S., Tuah, A. A., et al. (2016). Immortalized endothelial cell lines for in vitro blood-brain barrier models: a systematic review. Brain Res. 1642, 532-545. doi: 10.1016/j.brainres.2016.04.024

Reese, T. S., and Karnovsky, M. J. (1967). Fine structural localization of a bloodbrain barrier to exogenous peroxidase. J. Cell Biol. 34, 207-217. doi: 10.1083/ jcb.34.1.207

Risau, W., and Wolburg, H. (1990). Development of the blood-brain barrier. Trends Neurosci. 13, 174-178. doi: 10.1016/0166-2236(90)90043-A

Roudnicky, F., Kim, B. K., Lan, Y., Schmucki, R., Küppers, V., Christensen, K., et al. (2020a). Identification of a combination of transcription factors that synergistically increases endothelial cell barrier resistance. Sci. Rep. 10:3886. doi: 10.1038/s41598-020-60688-x

Roudnicky, F., Zhang, J. D., Kim, B. K., Pandya, N. J., Lan, Y., Sach-Peltason, L., et al. (2020b). Inducers of the endothelial cell barrier identified through -edited hPSC-endothelial cells. Proc. Natl. Acad. Sci. U.S.A. 117:19854. doi: 10.1073/pnas.1911532117 
Roux, F., and Couraud, P. O. (2005). Rat brain endothelial cell lines for the study of blood-brain barrier permeability and transport functions. Cell. Mol. Neurobiol. 25, 41-58. doi: 10.1007/s10571-004-1376-9

Roux, F., Durieu-Trautmann, O., Chaverot, N., Claire, M., Mailly, P., Bourre, J. M., et al. (1994). Regulation of gamma-glutamyl transpeptidase and alkaline phosphatase activities in immortalized rat brain microvessel endothelial cells. J. Cell. Physiol. 159, 101-113. doi: 10.1002/jcp.1041590114

Rubin, L. L., Hall, D. E., Porter, S., Barbu, K., Cannon, C., Horner, H. C., et al. (1991). A cell culture model of the blood-brain barrier. J. Cell Biol. 115, 1725-1735. doi: 10.1083/jcb.115.6.1725

Sances, S., Ho, R., Vatine, G., West, D., Laperle, A., Meyer, A., et al. (2018). Human iPSC-Derived endothelial cells and microengineered organ-chip enhance neuronal development. Stem Cell Rep. 10, 1222-1236. doi: 10.1016/j.stemcr. 2018.02.012

Saunders, N. R., Daneman, R., Dziegielewska, K. M., and Liddelow, S. A. (2013). Transporters of the blood-brain and blood-CSF interfaces in development and in the adult. Mol. Aspects Med. 34, 742-752. doi: 10.1016/j.mam.2012.11.006

Schaddelee, M. P., Voorwinden, H. L., van Tilburg, E. W., Pateman, T. J., Ijzerman, A. P., Danhof, M., et al. (2003). Functional role of adenosine receptor subtypes in the regulation of blood-brain barrier permeability: possible implications for the design of synthetic adenosine derivatives. Eur. J. Pharm. Sci. 19, 13-22. doi: 10.1016/s0928-0987(03)00034-4

Schulze, C., Smales, C., Rubin, L. L., and Staddon, J. M. (1997). Lysophosphatidic acid increases tight junction permeability in cultured brain endothelial cells. J. Neurochem. 68, 991-1000. doi: 10.1046/j.1471-4159.1997.68030991.x

Shawahna, R., Uchida, Y., Declèves, X., Ohtsuki, S., Yousif, S., Dauchy, S., et al. (2011). Transcriptomic and quantitative proteomic analysis of transporters and drug metabolizing enzymes in freshly isolated human brain microvessels. Mol. Pharm. 8, 1332-1341. doi: 10.1021/mp200129p

Siddharthan, V., Kim, Y. V., Liu, S., and Kim, K. S. (2007). Human astrocytes/astrocyte-conditioned medium and shear stress enhance the barrier properties of human brain microvascular endothelial cells. Brain Res. 1147, 39-50. doi: 10.1016/j.brainres.2007.02.029

Stebbins, M. J., Wilson, H. K., Canfield, S. G., Qian, T., Palecek, S. P., and Shusta, E. V. (2016). Differentiation and characterization of human pluripotent stem cell-derived brain microvascular endothelial cells. Methods 101, 93-102. doi: 10.1016/j.ymeth.2015.10.016

Stebbins Matthew, J., Lippmann Ethan, S., Faubion Madeline, G., Daneman, R., Palecek Sean, P., and Shusta Eric, V. (2017). Activation of RAR $\alpha, \operatorname{RAR} \gamma$, or $\mathrm{RXR} \alpha$ increases barrier tightness in human induced pluripotent stem cellderived brain endothelial cells. Biotechnol. J. 13:1700093. doi: 10.1002/biot. 201700093

Steinemann, A., Galm, I., Chip, S., Nitsch, C., and Maly, I. P. (2016). Claudin-1, -2 and -3 are selectively expressed in the epithelia of the choroid plexus of the mouse from early development and into adulthood while Claudin-5 is restricted to endothelial cells. Front. Neuroanat. 10:16. doi: 10.3389/fnana.2016.00016

Stenman, J. M., Rajagopal, J., Carroll, T. J., Ishibashi, M., McMahon, J., and McMahon, A. P. (2008). Canonical Wnt signaling regulates organ-specific assembly and differentiation of CNS vasculature. Science 322, 1247-1250. doi: $10.1126 /$ science. 1164594

Stins, M. F., Badger, J., and Sik Kim, K. (2001). Bacterial invasion and transcytosis in transfected human brain microvascular endothelial cells. Microb. Pathog. 30, 19-28. doi: 10.1006/mpat.2000.0406

Tam, S. J., Richmond, D. L., Kaminker, J. S., Modrusan, Z., Martin-McNulty, B., Cao, T. C., et al. (2012). Death receptors DR6 and TROY regulate brain vascular development. Dev. Cell 22, 403-417. doi: 10.1016/j.devcel.2011.11.018

Uchida, Y., Ohtsuki, S., Katsukura, Y., Ikeda, C., Suzuki, T., Kamiie, J., et al. (2011). Quantitative targeted absolute proteomics of human blood-brain barrier transporters and receptors. J. Neurochem. 117, 333-345. doi: 10.1111/ j.1471-4159.2011.07208.x

Urich, E., Lazic, S. E., Molnos, J., Wells, I., and Freskgård, P. O. (2012). Transcriptional profiling of human brain endothelial cells reveals key properties crucial for predictive in vitro blood-brain barrier models. PLoS One 7:e38149. doi: 10.1371/journal.pone.0038149

Vanlandewijck, M., He, L., Mae, M. A., Andrae, J., Ando, K., Del Gaudio, F., et al. (2018). A molecular atlas of cell types and zonation in the brain vasculature. Nature 554, 475-480. doi: 10.1038/nature25739

Vatine, G. D., Al-Ahmad, A., Barriga, B. K., Svendsen, S., Salim, A., Garcia, L., et al. (2017). Modeling psychomotor retardation using iPSCs from MCT8-deficient patients indicates a prominent role for the blood-brain barrier. Cell Stem Cell 20, 831-843.e835. doi: 10.1016/j.stem.2017.04.002

Vatine, G. D., Barrile, R., Workman, M. J., Sances, S., Barriga, B. K., Rahnama, M., et al. (2019). Human iPSC-derived blood-brain barrier chips enable disease modeling and personalized medicine applications. Cell Stem Cell 24, 9951005.e1006. doi: 10.1016/j.stem.2019.05.011

Veszelka, S., Tóth, A., Walter, F. R., Tóth, A. E., Gróf, I., Mészáros, M., et al. (2018). Comparison of a rat primary cell-based blood-brain barrier model with epithelial and brain endothelial cell lines: gene expression and drug transport. Front. Mol. Neurosci. 11:166. doi: 10.3389/fnmol.2018.00166

Wagner, E. F., and Risau, W. (1994). Oncogenes in the study of endothelial cell growth and differentiation. Semin. Cancer Biol. 5, 137-145.

Warren, M. S., Zerangue, N., Woodford, K., Roberts, L. M., Tate, E. H., Feng, B., et al. (2009). Comparative gene expression profiles of ABC transporters in brain microvessel endothelial cells and brain in five species including human. Pharmacol. Res. 59, 404-413. doi: 10.1016/j.phrs.2009.02.007

Watson, P. M., Paterson, J. C., Thom, G., Ginman, U., Lundquist, S., and Webster, C. I. (2013). Modelling the endothelial blood-CNS barriers: a method for the production of robust in vitro models of the rat blood-brain barrier and blood-spinal cord barrier. BMC Neurosci 14:59. doi: 10.1186/1471-2202-14-59

Weksler, B., Romero, I. A., and Couraud, P. O. (2013). The hCMEC/D3 cell line as a model of the human blood brain barrier. Fluids Barriers CNS 10:16. doi: 10.1186/2045-8118-10-16

Weksler, B. B., Subileau, E. A., Perrière, N., Charneau, P., Holloway, K., Leveque, M., et al. (2005). Blood-brain barrier-specific properties of a human adult brain endothelial cell line. FASEB J. 19, 1872-1874. doi: 10.1096/fj.04-3458fje

Westergaard, E., and Brightman, M. W. (1973). Transport of proteins across normal cerebral arterioles. J. Comp. Neurol. 152, 17-44. doi: 10.1002/cne. 901520103

Wilson, H. K., Canfield, S. G., Hjortness, M. K., Palecek, S. P., and Shusta, E. V. (2015). Exploring the effects of cell seeding density on the differentiation of human pluripotent stem cells to brain microvascular endothelial cells. Fluids Barriers CNS 12:13. doi: 10.1186/s12987-015-0007-9

Wolburg, H., Neuhaus, J., Kniesel, U., Krauss, B., Schmid, E. M., Ocalan, M., et al. (1994). Modulation of tight junction structure in blood-brain barrier endothelial cells. Effects of tissue culture, second messengers and cocultured astrocytes. J. Cell Sci. 107(Pt 5), 1347-1357.

Wolburg, H., Wolburg-Buchholz, K., Kraus, J., Rascher-Eggstein, G., Liebner, S., Hamm, S., et al. (2003). Localization of claudin-3 in tight junctions of the blood-brain barrier is selectively lost during experimental autoimmune encephalomyelitis and human glioblastoma multiforme. Acta Neuropathol. 105, 586-592. doi: 10.1007/s00401-003-0688-Z

Yusof, S. R., Avdeef, A., and Abbott, N. J. (2014). In vitro porcine blood-brain barrier model for permeability studies: pCEL-X software pKa(FLUX) method for aqueous boundary layer correction and detailed data analysis. Eur. J. Pharm. Sci. 65, 98-111. doi: 10.1016/j.ejps.2014.09.009

Zhang, Y., Li, C. S., Ye, Y., Johnson, K., Poe, J., Johnson, S., et al. (2006). Porcine brain microvessel endothelial cells as an in vitro model to predict in vivo bloodbrain barrier permeability. Drug Metab. Dispos. 34, 1935-1943. doi: 10.1124/ dmd.105.006437

Zhang Rui, L., Chopp, M., Jiang, N., Tang Wen, X., Prostak, J., Manning Anthony, M., et al. (1995). Anti-intercellular adhesion molecule-1 antibody reduces ischemic cell damage after transient but not permanent middle cerebral artery occlusion in the wistar rat. Stroke 26, 1438-1443. doi: 10.1161/01.STR.26.8.1438

Zlokovic, B. V. (2008). The blood-brain barrier in health and chronic neurodegenerative disorders. Neuron 57, 178-201. doi: 10.1016/j.neuron.2008. 01.003

Conflict of Interest: The authors declare that the research was conducted in the absence of any commercial or financial relationships that could be construed as a potential conflict of interest.

Copyright (c) 2021 Lu, Barcia Durán, Houghton, Rafii, Redmond and Lis. This is an open-access article distributed under the terms of the Creative Commons Attribution License (CC BY). The use, distribution or reproduction in other forums is permitted, provided the original author(s) and the copyright owner(s) are credited and that the original publication in this journal is cited, in accordance with accepted academic practice. No use, distribution or reproduction is permitted which does not comply with these terms. 